\title{
POST MORTEM MODIFICATIONS (PSEUDOPALEOPATHOLOGIES) IN MIDDLE- LATE PLEISTOCENE MAMMAL FOSSILS FROM SOUTHERN BRAZIL
}

\author{
RENATO PEREIRA LOPES \\ Instituto de Geociências, UFRGS, Avenida Bento Gonçalves, 9500, 91540-000, Porto Alegre, RS, Brazil. \\ paleonto_furg@yahoo.com.br \\ JORGE FERIGOLO \\ Seção de Paleontologia, Museu de Ciências Naturais, Fundação Zoobotânica do Rio Grande do Sul, \\ Av. Salvador França, 1427, 90690-000, Porto Alegre, RS, Brazil. \\ jorgeferigolo@gmail.com
}

\begin{abstract}
Here are described post mortem modifications (pseudopaleopathologies) in 762 specimens of extinct mammals from three middle to late Pleistocene assemblages (Campanha, Chuí Creek and continental shelf) of the state of Rio Grande do Sul, southern Brazil. These assemblages include mostly large-sized herbivores preserved in fluvial facies, although the assemblage from the shelf consist of remains that were reworked several times by sea-level oscillations. Although some patterns of modification are similar between the assemblages (e.g. post-fossilization plain fractures), others such as the grade of abrasion or weathering varies according to the depositional setting. The scarcity of modifications that could be attributed to predators or scavengers indicate that carnivory was not a major process driving the formation of the assemblages. Most of the fossils from the Campanha are complete, but a relatively high proportion of them exhibits advanced stage of weathering, whereas those from Chuí Creek and the continental shelf are mostly unweathered. Most of the remains from the Campanha and Chuí Creek are unabraded, whereas all fossils from the shelf were subject to abrasion. Few fossils exhibit signs of modification by organisms such as plants and insects. Fossils from the continental shelf have crusts of beach rock, and some specimens from the Campanha and Chuí Creek have crusts of calcium carbonate or iron oxide. Besides the abrasion, the main difference between fossils from the continental and marine assemblages is the dark color and higher mechanical resistance of the latter. This difference is related to post depositional geochemical processes in the marine environment. The chemical composition of fossils from Chuí Creek and continental shelf was qualitatively analyzed using energy dispersive X-ray spectrometry (EDX) and compared with recent bones. The results show the presence in the fossils of several elements not found in recent bones, incorporated through diagenetic processes controlled by specific conditions of each depositional environment.
\end{abstract}

Key words: pseudopaleopathology, taphonomy, Quaternary, Pleistocene, megafauna, diagenesis.

RESUMO - Aqui são descritas modificações post mortem (pseudopaleopatologias) em 762 fósseis de mamíferos extintos de três assembleias do Pleistoceno médio e tardio (Campanha, Arroio Chuí e plataforma continental) do estado do Rio Grande do Sul, sul do Brasil. Estas assembleias incluem predominantemente herbívoros de grande porte preservados em fácies fluviais, embora a assembleia da plataforma continental consista de restos que foram diversas vezes sujeitos a retrabalhamento por oscilações do nível do mar. Embora alguns padrões de modificação sejam similares entre as assembleias (e.g. fraturas planas pós-fossilização), outros como o grau de abrasão ou intemperismo variam de acordo com o contexto deposicional. A escassez de modificações que possam ser atribuídas a predadores ou carniceiros indica que carnivoria não foi um processo determinante na formação das assembleias. A maioria dos fósseis da Campanha é completa, mas uma proporção relativamente elevada apresenta estágio avançado de intemperismo, enquanto no Arroio Chuí e plataforma são predominantemente nãointemperizados. A maioria dos restos da Campanha e Arroio Chuí não são abradidos, mas todos os da plataforma foram sujeitos a abrasão. Poucos fósseis exibem sinais de modificação por organismos como plantas ou insetos. Fósseis da plataforma têm crostas de arenitos praiais, e alguns espécimes da Campanha e Arroio Chuí têm incrustações de carbonato de cálcio ou óxido de ferro. Além da abrasão, a principal diferença entre os fósseis das assembleias continentais e marinha é a coloração escura e maior resistência mecânica nestes últimos. Esta diferença está relacionada a processos geoquímicos pós-deposicionais no ambiente marinho. A composição química de fósseis do Arroio Chuí e plataforma continental foi quantitativamente analisada através de espectrometria dispersiva de raios-X (EDX), e comparada com ossos atuais. Os resultados mostram a presença nos fósseis de diversos elementos não encontrados nos ossos recentes, incorporados por processos diagenéticos controlados por condições específicas de cada ambiente deposicional.

Palavras-chave: pseudopaleopatologia, tafonomia, Quaternário, Pleistoceno, megafauna, diagênese. 


\section{INTRODUCTION}

Bones are complex structures that contain several types of information (anatomical, taxonomical, isotopic, molecular, biochemical and structural), each one relevant for several kinds of studies (Hedges, 2002). Bones perform the mechanical functions of fixation for the muscles and support, but also provide space for the blood-forming tissues and protection for the internal organs. Its main protein component is collagen (about 90\%), while the main mineral phase is carbonated calcium phosphate [hydroxiapatite, $\mathrm{Ca}_{10}\left(\mathrm{CO}_{3} \mathrm{PO}_{4}\right)_{6}(\mathrm{OH})_{2}$ ] (Ortner \& Putschar, 1980; Trueman \& Tuross, 2002). The endoskeleton of vertebrate animals consists of bones of distinct shape and sizes, seldom preserved in articulation after death. Good skeletal preservation is achieved only under very specific conditions such as quick burial or deposition in stagnant or calm water bodies, where hydrodynamics does not affect the bottom, which becomes anoxic. These conditions prevent disarticulation and scattering of the skeletal elements by environmental (waves, currents) or biological (scavenging) processes.

Disarticulation of the skeleton follows a defined pattern according to a higher or lower degree of articulation between elements. In semiarid areas, the mummification by desiccation of tendons, ligaments and skin may result in the burial of the entire skeleton (Toots, 1965; Hill, 1979). Predators and scavengers can also contribute for disarticulation, mostly of the more nutritive elements such as limbs (D’Andrea \& Gotthardt, 1984). Hydraulic transport and predators / scavengers are the main responsible for the removal, dispersion and destruction of bones. Those that survive this initial destruction and are buried become subject to several chemical processes that result in significant alteration of their composition and microstructure, transforming bones in fossils (Hedges, 2002).

Considering that the structure of the bones can be subject to several types of modifications, either on micro and macroscopic scales, during life and after death, by biotic and abiotic processes, and that such modifications can be used as tools for reconstructing the life history, paleoenvironments and original depositional settings, it is important to distinguish between modifications caused during life (ante mortem) from those caused after death (post mortem) of the individuals.

The signs left by post mortem processes in vertebrate remains depend on the structure and composition of bones, and the mechanisms that may affect the remains. The distinct fracturing patterns in fresh (unfossilized) and fossil bone, for example, are related to its elasticity, which in turn depends on its water and protein (collagen) content. The loss of water and degradation of the collagen in fossilized bones result in fractures (that may be produced by mechanisms such as trampling or fluvial transport) with plain edges that are transverse to the major axis; in fresh remains, the fractures are irregular and usually follow a spiral pattern along the major axis of the bone (Holz \& Simões, 2002). Another major difference between ante and post mortem fractures is the presence of signs of healing in the former, in cases when the organism continued living for some time after the fracture was produced (Ferigolo, 2007; Waldron, 2009).
In order to evaluate the ante mortem and post mortem processes that affect vertebrate remains, it is of paramount importance to correctly identify and distinguish the signs left in the skeleton by these processes. Paleopathologies are the signs of modifications produced in ancient human and non-human remains by trauma, chronic diseases or processes related to senility, but may also result from reaction of the tissues to etiological agents (Ferigolo, 2007). While paleopathologies result from processes that affect the remains prior to death (or may be the cause of death), post mortem modifications, defined as pseudopathologies, are caused by distinct phenomena (Aufderheide \& Rodríguez-Martín, 1998). Following this rationale, pseudopaleopathologies can be defined as modifications in ancient remains produced by post mortem processes (Ferigolo, 2007). It is important to distinguish paleopathologies from pseudopaleopathologies in order to avoid erroneous diagnostics or conclusions regarding the taphonomic history of fossil remains.

The understanding of the processes that influence the transition of organic remains from the biosphere to the lithosphere is the main object of taphonomy (Efremov, 1940). This transition is driven by processes controlled by the nature of the depositional environment, therefore, post mortem alterations in fossils can serve as tools for paleoenvironmental reconstructions (Brett \& Baird, 1986). In recent years, more attention has been given to the information provided by these alterations, as opposed to the loss of paleoecological information (Behrensmeyer \& Kidwell, 1985). Taphonomic reconstructions rely on information obtained from fossils, depositional, and stratigraphic context of the fossil-bearing strata (Behrensmeyer, 1991; Holz \& Simões, 2002). The taphonomic-related paleontological studies on vertebrate remains, however, have focused mostly on the overall preservational context of fossil assemblages (e.g. Badgley et al., 1995; Holz \& Souto-Ribeiro, 2000; Palmqvist \& Arribas, 2001) while little attention has been given to the modifications on the skeletal remains themselves. The available studies about skeletal modifications are based mostly on archaeological or recent remains (Behrensmeyer, 1978; Bell et al., 1996; Cutler, et al. 1999; Mello, 1999; Jans et al., 2002; Bartosiewicz, 2008). These studies have also revealed specific patterns that indicate modification of skeletal remains by human action (Selvaggio, 1994; Lyman, 2005), predation and scavenging (Fernández-Jalvo \& Andrews, 1992; Montalvo et al., 2008) and even cannibalism among humans (Defleur et al., 1999).

The presence of fossil mammals in Rio Grande do Sul State is known since the late 19th Century. Throughout the 20th Century, several fossiliferous localities were discovered, including the Chuí Creek (in the Coastal Plain of Rio Grande do Sul state) and Touro Passo Creek (western Rio Grande do Sul). These fossils have been the object of several taxonomic studies (e.g. Cunha, 1959; Paula Couto \& Cunha, 1965; Bombin, 1976; Oliveira, 1992; Rodrigues \& Ferigolo, 2004; Pitana et al., 2005; Scherer et al., 2007; Kerber \& Oliveira, 2008).

Here are presented the results of a survey on mammalian remains from three Pleistocene fossil assemblages of Rio 
Grande do Sul: Touro Passo Formation, Santa Vitória Formation and the continental shelf (Figure 1). The aim of this survey was to identify, describe, categorize and analyze the patterns of macroscopic post mortem modifications of these remains and to evaluate the presence of differences between the sites. In theory, there may be differences in preservation between the sites, owing to specific post depositional conditions.

\section{GEOLOGICAL SETTING}

In western Rio Grande do Sul state (known as the Campanha), Quaternary vertebrate fossils are found in sedimentary layers exposed along several fluvial systems of the Uruguay River basin, such as the Quaraí and Ibicuí rivers and the Touro Passo Creek (Da Rosa, 2009). The geology and stratigraphy of the Quaternary continental deposits of Rio Grande do Sul is still poorly defined; only two formal geological units have been proposed so far for these deposits: the Touro Passo Formation (Bombin, 1976) and the Guterrez Alloformation (Da Rosa \& Milder, 2001), but the latter did not provide vertebrate remains so far. Besides the Touro Passo Formation, fossil remains can be found in several other outcrops, but without well-defined stratigraphic setting (Da Rosa, 2009).

\section{The Touro Passo Formation}

The well-studied fossil-bearing outcrops in the Campanha are exposed along the Touro Passo Creek, close to the town of Uruguaiana (Figure 1B). Bombin (1976) described the geology of these outcrops and defined the Touro Passo Formation based on the sedimentary sequence exposed along the creek. This formation unconformably overlies altered basaltic rocks of the Serra Geral Formation (Cretaceous) and is divided into two units: the basal Rudaceous Member, which is composed by conglomerates deposited in anastomosed fluvial systems, and the overlying Muddy Member, composed by silt and clay with subordinated silty sand layers, deposited in floodplain environments (Figure 1B). The upper portion of this member exhibits a carbonate horizon (IICCa) measuring less than one meter in thickness. This carbonate layer was correlated to the "Caliche Cordão" found in the coastal plain, presumably formed under similar climatic conditions (Bombin \& Klamt, 1975).

Both Rudaceous and Muddy members contain vertebrate remains, but well-preserved, in situ fossils were found only on the latter so far. Besides mammals, fossils of chelonians, freshwater bivalves and tree trunks were also found (Da Rosa, 2009; Ribeiro \& Scherer, 2009). Thermoluminescence (TL) datings revealed ages between $\sim 43$ and 6 thousand years for this Formation (Da Rosa, 2003), while electron spin resonance (ESR) datings provided ages between 34 and 19 thousand years for the mammalian remains (Kerber et al., 2011a; Figure 2). The ages and faunal composition indicate that this assemblage belongs to the Lujanian Stage/Age. Outcrops of this formation were also recognized along the banks of other fluvial systems, such as Imbaá Creek, Sanga da Cruz and Quaraí River (Da Rosa, 2009).
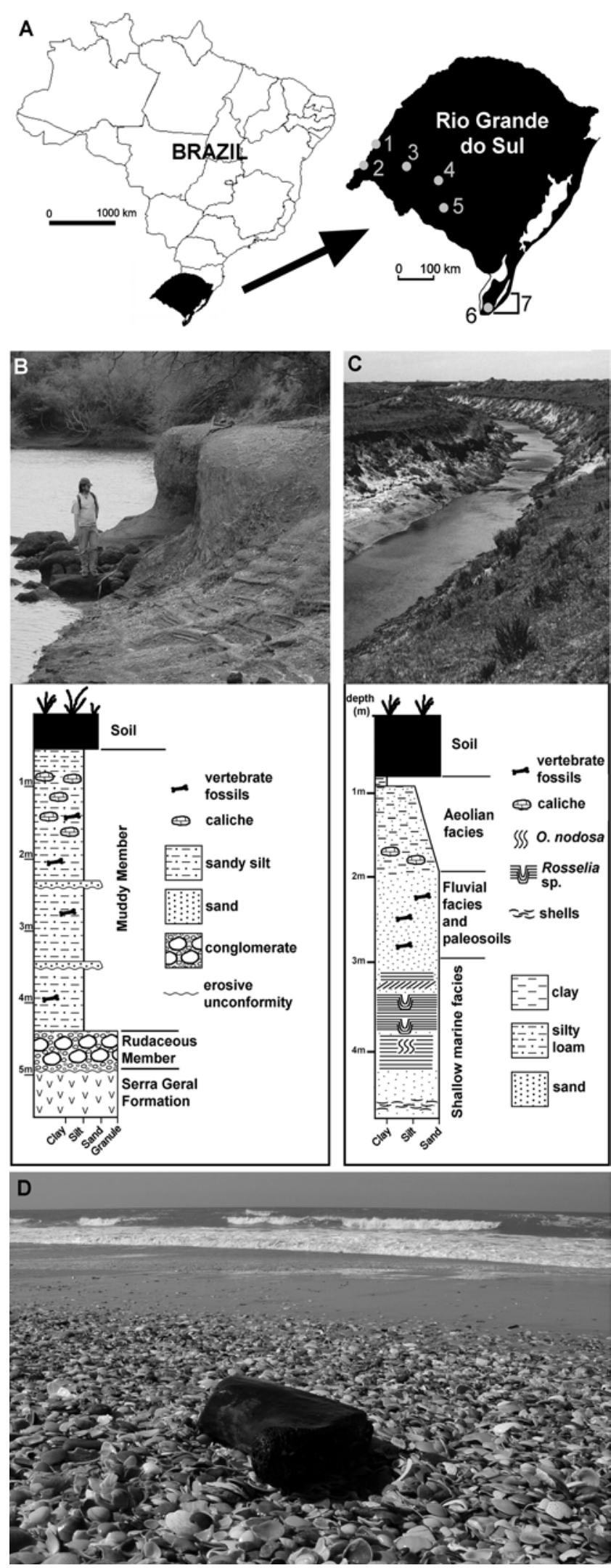

Figure 1. A, Pleistocene fossil localities in Rio Grande do Sul State (1, Itaqui; 2, Uruguaiana; 3, Alegrete; 4, Rosário do Sul; 5, Dom Pedrito; 6, Arroio Chuí; 7, Concheiros); B, outcrops and stratigraphy of the Touro Passo Formation; $\mathbf{C}$, Chuí Creek and stratigraphic section of its banks; D, mammalian fossil from the continental shelf stranded on the beach by storm events. 


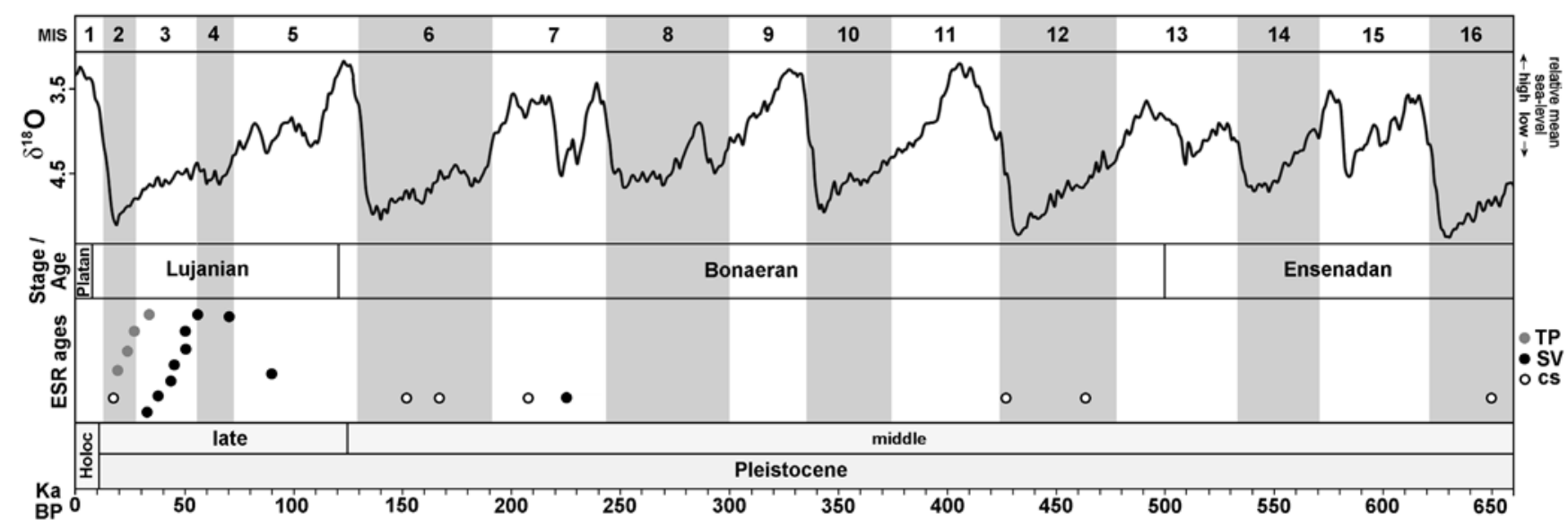

Figure 2. ESR ages of mammalian remains from the three assemblages, superimposed to glacial (shaded) and interglacial stages $\left(\delta^{18} \mathrm{O}\right.$ curves from Lisiecki \& Raymo, 2005) and South America biostratigraphic Stages/Ages (following Cione \& Tonni, 1999). Abbreviations: cs, continental shelf; ESR, electron spin resonance; SV, Santa Vitória Formation; TP, Touro Passo Formation.

\section{Chuí Creek}

In the Coastal Plain of Rio Grande do Sul state (CPRS), fossils of mammals are found in fluvial facies of the Santa Vitória Formation, exposed along the banks of Chuí Creek, and on the continental shelf (Figure 1A). The CPRS is part of the uppermost portion of the Pelotas Basin, a marginal sedimentary basin composed of terrigenous clastic sediments deposited in the coastal area of southern Brazil by rivers and detrital fluxes after the split between South America and Africa in the Late Cretaceous (Villwock \& Tomazelli, 1995). During the Quaternary, glacioeustatic oscillations reworked the upper sediments of the Pelotas Basin and formed two major depositional systems that constitute the CPRS: the Alluvial Fans System and four Barrier-Lagoon Systems. The Alluvial Fans System was deposited in marine and terrestrial environments between the Miocene and Pliocene, while each Barrier-Lagoon System was formed by a sea-level highstand during interglacial epochs (Villwock \& Tomazelli, 1995).

Chuí Creek is a small fluvial system located in the southern portion of the CPRS, in the Santa Vitória do Palmar County. It flows in a NE-SW direction, through a large plain positioned between the Pleistocene coastal barriers II and III. The stratigraphic sequence observed along the creek consists of a 2 meter-thick basal layer exposed above the creek bed (Figure 1C). This unit is the Chuí Formation of Delaney (1965), composed of fine and medium sand with cross and parallel stratification; the fossils from this unit include foraminifera, ostracods, molluscan shells and ichnofossils Ophiomorpha nodosa and Rosselia isp., which indicate shallow (upper shoreface) marine environment (Lopes et al., 2009, 2014).

The overlying 1 meter-thick layer is composed of fine, muddy sand with root traces that indicate paleosoils, and fossil-bearing fluvial facies; at some points, dark sand lenses interpreted as oxbow lakes formed in meandering fluvial systems are found. This layer is the Santa Vitória Formation of Soliani (1973). The mammalian fauna from the fluvial facies consists mostly of large ( $>1000 \mathrm{~kg}$ ) herbivores, although carnivore and rodent remains have been described from this deposit (Oliveira et al., 2005; Ubilla et al., 2008; Kerber et al., 2011b, 2012). ESR datings in mammal teeth from the fossiliferous layer shows ages between 226 and 33 thousand years (Lopes et al., 2010, 2014), therefore this assemblage belongs to Bonaeran and Lujanian Stage/Ages (Figure 2). The fossils include mostly disarticulated and isolated remains, but a few associated and even articulated specimens were also found.

The sediments overlying the fossiliferous horizon exhibit an upwards increase in silt-sized particles that represents loessic deposition during the last glacial maximum; in its lower half, calcium carbonate nodules and rhizocretions (sensu Klappa, 1980), called “Caliche Cordão” by Delaney (1965) are abundant (Lopes et al., 2011). Large mammals have not been found in this layer so far. The uppermost portion of the sequence consists of a $~ 50$ centimeter-thick clayey, organic matter-rich sand containing freshwater bivalves, vertebrate and paleoindian remains of Holocene age (Schmitz et al., 1997).

\section{Continental shelf}

Fossils of terrestrial mammals occur along the continental shelf up to depths of about $40 \mathrm{~m}$ (Lopes \& Buchmann, 2010). ESR datings on teeth from the shelf showed ages ranging from $\sim 650$ thousand to 18 thousand years, encompassing Ensenada, Bonaeran and Lujanian Stages/Ages (Figure 2). The ages correspond to periods of sea-level lowstands, indicating that terrestrial environments occupied the shelf during glacial stages. During the intervening interglacial stages, marine transgressions reworked and eroded these deposits, mixing together remains of different ages (Buchmann et al., 2009; Lopes et al., 2010; Lopes \& Buchmann, 2010).

Virtually all knowledge regarding these fossils was obtained from remains collected from large konzentrattlagerstätte known as the Concheiros, a $\sim 40 \mathrm{~km}-$ long portion of the coastline between Brazil and Uruguay where molluscan and vertebrate fossil remains are transported from submerged deposits and accumulated in the upper shoreface- 
backshore by storm waves (Figure 1D). Some mammalian remains were collected directly from the continental shelf by research and fishing vessels (Lopes \& Buchmann, 2010). The exact stratigraphic setting of these remains is unknown, because of the multiple re-working of the deposits by successive sea-level oscillations, but it is likely that these were preserved in fluvial systems flowing through the shelf during glacial epochs, when this was subaerially exposed because of sea-level lowstands (Dillenburg, 1994; Lopes \& Buchmann, 2010).

\section{MATERIAL AND METHODS}

The analyzed specimens belong to the paleontological collections of Fundação Zoobotânica do Rio Grande do Sul and Universidade Federal do Rio Grande. The specimens were collected during the last 35 years in outcrops of western Rio Grande do Sul (Campanha Region, mostly from Touro Passo Creek, Uruguaiana County) and the Coastal Plain of Rio Grande do Sul state (Concheiros and Chuí Creek, Santa Vitória do Palmar County).

Considering that the specimens come from different depositional settings, a comparison can be made to evaluate similarities and differences that may indicate specific preservation processes. In order to understand the patterns of modifications, fossils from the different areas were subject to a quali-quantitative comparison. A total of 241 fossil specimens from the Campanha Region (185 from Touro Passo Creek and 56 from other locations), and 266 from Chuí Creek and 255 from the continental shelf were analyzed. The specimens were identified to the lowest taxonomic level, and the different types of skeletal elements were divided according to Voorhies' groups. Each group encompasses skeletal elements with similar hydraulic properties, and the relative proportions of elements of each group in assemblages can indicate hydraulic sorting (Voorhies, 1969).

These groups encompass small and compact bones such as phalanges, osteoderms and carpals that are easily transported by weak currents (group I), bones that require stronger currents for its transportation such as femora and humeri (group II) and bones that are transported only by very strong currents such as cranial elements, jaws and teeth (group III). Because the elements from these groups exhibit distinct characteristics, it would presumably be possible to assess the presence of specific preservation patterns related to their transportability, shape and size.

For each fossil specimen a series of macroscopic physical features were observed, following the protocol proposed by Behrensmeyer (1991) with minor adaptations. The features included physical integrity, which defines the fossils in terms of completeness. The remains were classified as complete, incomplete (when less than $50 \%$ of the bone was lost) or fragments (when more than $50 \%$ of the bone was lost).

The exposition of bones to weathering processes leaves distinct cracking patterns; this parameter was classified following the work of Behrensmeyer (1978), using the stages identified by that author to describe progressive weathering of mammalian remains. The stage attributed to each fossil was that visible in an area larger than $1 \mathrm{~cm}^{2}$ on the specimens, which were classified as stage 0 (unweathered remains), stage 1 (only surface crackings) or stage 2 (remains with deep crackings). For the goal of the present analysis, the term cracking designates surface damage to the fossils without causing their destruction, whereas fracture describes cases where the fossils were broken, with physical separation between the parts.

Another feature analyzed was the presence of signs of abrasion, produced by mechanical processes related to transportation of the remains; these signs include smooth surfaces or rounded edges. The fossils were classified as grade 0 (unabraded remains), grade 1 (only surface abrasion) or grade 2 (remains with more than $50 \%$ of the surface abraded, or with the internal structure exposed because of abrasion).

The presence or absence of other modifications was also evaluated, and when possible, the causes of these marks were inferred. The processes that can cause such modifications include predation and/or scavenging, human action, plant growth and burrowing by invertebrates. The latter include mostly traces left by insects, grouped into five categories (Moura et al., 1997; Bharti \& Singh, 2003; Pirrone et al., 2014):

- Cubiculum (ovoid chambers produced by larvae of dermestid beetles)

- Rounded to elliptical shallow holes (also produced by dermestid beetles)

- Radial shallow depressions (assigned to termites and larvae of tineid moths)

- Osteocallis (shallow irregular trails produced by silphid and histerid beetles)

- Subcortical tunnels and cavities (produced by scavengers).

As an attempt to understand the nature of variations in color and mechanical resistance of the remains, some fossil samples from Chuí Creek and the continental shelf, plus recent bones, were analyzed using energy dispersive $\mathrm{X}$-ray spectroscopy (EDX). This technique provides information on the chemical composition of a sample based on the amount of X-ray energy released by the sample when subject to a beam of high-energy particles. The EDX is a qualitative technique that shows the composition of a sample but not its crystalline structure; it can discriminate the elements of the periodic table from sodium to scandium and from titanium to uranium, but does not identify carbon, lithium and beryllium. The analyses were performed at the Laboratório de Engenharia de Materiais of Universidade Federal de Pelotas. The specimens included one osteoderm of a recent armadillo, two fossil osteoderms of armadillos from the continental shelf (specimens LGP-N0217 and N0218), one fragment of a fossil rib collected in Chuí Creek, and one rib from a recently dead cow found near the creek.

Intitutional abbreviations: FURG, Universidade Federal do Rio Grande, Rio Grande, RS, Brazil; FZBRS, Fundação Zoobotânica do Rio Grande do Sul, Porto Alegre, RS, Brazil; LGP, paleontological collection of Universidade Federal do Rio Grande, Rio Grande, Brazil; MCN-PV, paleovertebrate collection of Museu de Ciências Naturais, Fundação 
Zoobotânica do Rio Grande do Sul, Porto Alegre, Brazil; UFPel, Universidade Federal de Pelotas, Pelotas, RS, Brazil.

\section{RESULTS}

\section{Fossils from the Campanha Region}

Most of the fossils from the Campanha (185 specimens) were collected in the outcrops of the Touro Passo Formation (Uruguaiana County). Other remains came from the Passo do Juquiry (9 specimens), Quaraí (2) and Pindaí-mirim (1) rivers, all of them in Uruguaiana County; from the Campo Seco locality (Rosário do Sul County) came 34 remains of a single individual of Notiomastodon waringi (Marcon, 2007), plus one tibia of a mylodontid sloth. Five specimens were found in the Ibicuí River (Itaqui County), one in Alegrete, and one in Dom Pedrito.

The identified taxa from the Campanha include medium to large-size herbivores (Table 1). The most common skeletal elements belong to Voorhies' group I (169 specimens), followed by elements of group II (39 specimens) and group III (21 elements), whereas 12 other specimens are fragments that could not be assigned to any group (Table 2). Osteoderms of Pampatherium are the most numerous elements of group I (57 specimens), followed by osteoderms of Glyptodon (35 specimens).

Most fossils are complete (92 specimens), followed by incomplete (79 specimens) and fragments (72 specimens). Advanced signs of weathering (stage 2) was observed in 110 fossils (Figure 3A), whereas 75 exhibit no signs of weathering (stage 0 ) and 56 exhibit only surface weathering (stage 1). Weathering signs are visible as longitudinal fractures in long bones and irregular, reticulated fracturing pattern in convex and concave surfaces (e.g. femora heads, acetabula); teeth exhibit less weathering features than bones (Figure 3B). 223 specimens were classified as unabraded (grade 0) and 18 specimens exhibit abrasion grade 1 ; none exhibit abrasion grade 2 .

Several fossils (109 specimens) exhibit calcium carbonate cement either externally (forming crusts) or internally (filling up cavities, Figure 3C); these include two unweathered specimens (stage 0) 14 assigned to stage 1 , and 82 to stage 2. Precipitation of calcium carbonate cement around disarticulated osteoderms of Pampatherium and mylodontid sloths prevented the scattering of these specimens (Figure $3 \mathrm{D})$; in some cases, the expansion of the carbonate by recrystallization seems to be responsible for irregular fractures throughout the bone (FigureS 3E, F). In a pair of ursid vertebrae and a cervid antler (Antifer sp., Figure $3 \mathrm{G})$, the carbonate precipitated around plant roots that were growing directly on the bones, forming root tubules (mineral precipitations around hollow tubes left by decayed roots) and root casts, formed by carbonate that filled hollow spaces left by decayed roots, sensu Klappa (1980).

No signs that could be related to predators or scavengers were identified, but the ulna of an ursid and one unidentified bone (Figure $3 \mathrm{H}$ ), exhibit galleries and holes probably produced by insect larvae. Another ulna of a ground sloth exhibits shallow, irregular grooves forming dendritic patterns on its surface (Figure 3I). Several bones of Toxodon, probably from the same individual, are remarkably well-preserved, with an almost pristine appearance. Most of the fossils are white or light brown, but four camelid and one cervid specimen are dark brown, as seen in some fossils from the Chuí Creek.

\section{Fossils from Chuí Creek}

The taxa found in the fossiliferous layer exposed along this creek are mostly large-sized herbivores, but some carnivores and rodents have been described from this area (Oliveira et al., 2005; Ubilla et al. 2008; Kerber et al., 2011b; 2012; Pereira et al., 2012). Only large- and medium-sized herbivores were present among the analyzed specimens (Table 1). The most common skeletal elements belong to the Voorhies' group I (150 specimens), followed by 16 of group II and 34 of group III, plus 66 fragments that could not be assigned to any of these groups (Table 2). The total number of complete specimens is 40 , whereas 72 are incomplete and 154 are fragments. The larger proportion of complete specimens and fragments is represented by elements of the Voorhies' group I (mostly glyptodontid osteoderms, Figure 4A), whereas elements of groups II and III are mostly fragments.

The majority of the incomplete and fragmented fossils exhibit plain fractures; the only observed exception is a cervid tibia which exhibits an irregular pattern of fracturing on its proximal end (Figure 4B). One almost complete jaw of Toxodon exhibits irregular plain fractures (Figure 4C).

Most specimens from Chuí Creek are disarticulated, isolated elements, and usually parts of different taxa are found associated. Few articulated remains have been discovered so far; one example is an incomplete skeleton of a mylodontid sloth, represented by part of the vertebral column (Figure 4D) and other elements including osteoderms. Although exposed recently by erosion of the banks, these remains do not exhibit signs of abrasion or weathering.

Most of the fossils (212 specimens) do not exhibit signs of weathering (stage 0 ), followed by 50 that exhibit weathering stage 1 , including the aforementioned tibia. Only four specimens exhibit weathering stage 2, in the form of deep longitudinal crackings (Figure 4E). 195 specimens do not exhibit signs of abrasion, whereas abrasion grade 1 , in the form of rounded edges, was observed in 54 specimens and grade 2 in 17 specimens (Figure 4F). One unciform bone, a partial scapula and a rib fragment exhibit shallow, irregular dark dendritic grooves (Figure 4G). The cervid tibia (Figure $4 \mathrm{~B})$ exhibits faint, shallow parallel scratches oblique to the longer axis of the bone.

The specimens from the fossiliferous layer range in colour from light brown to light pink; those that remained exposed for some time due to erosion of the banks exhibit whitish colour. Fossils that have been exposed to water are total or partially darkened (Figure $4 \mathrm{H}$ ). Although the caliche reaches the fossiliferous horizon, few specimens so far were found directly associated with this material; one of them (Figure 4I) is a fragment of a cervid (Morenelaphus sp.) antler, but this was found among sediments removed from a 

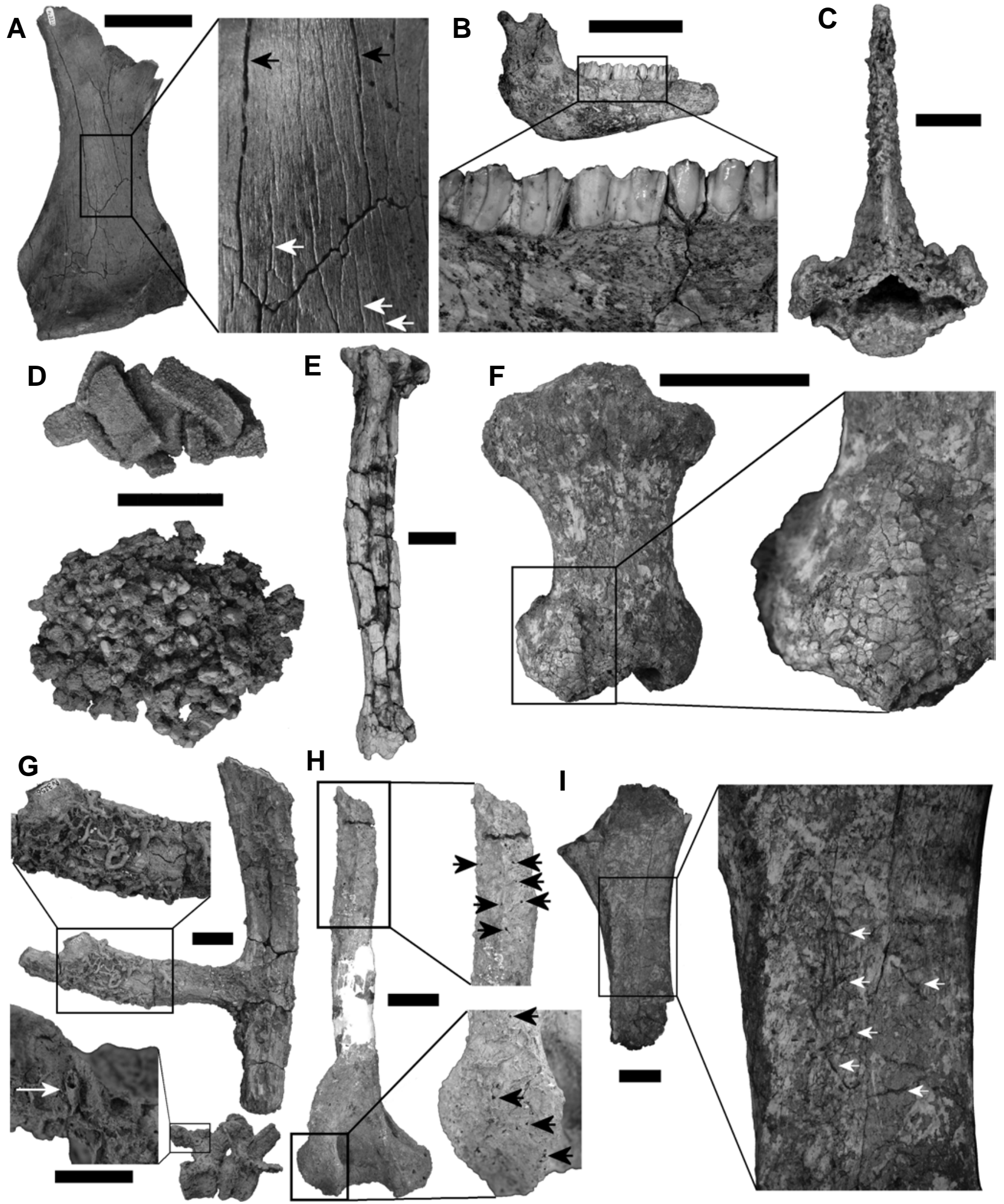

$\mathrm{H}$
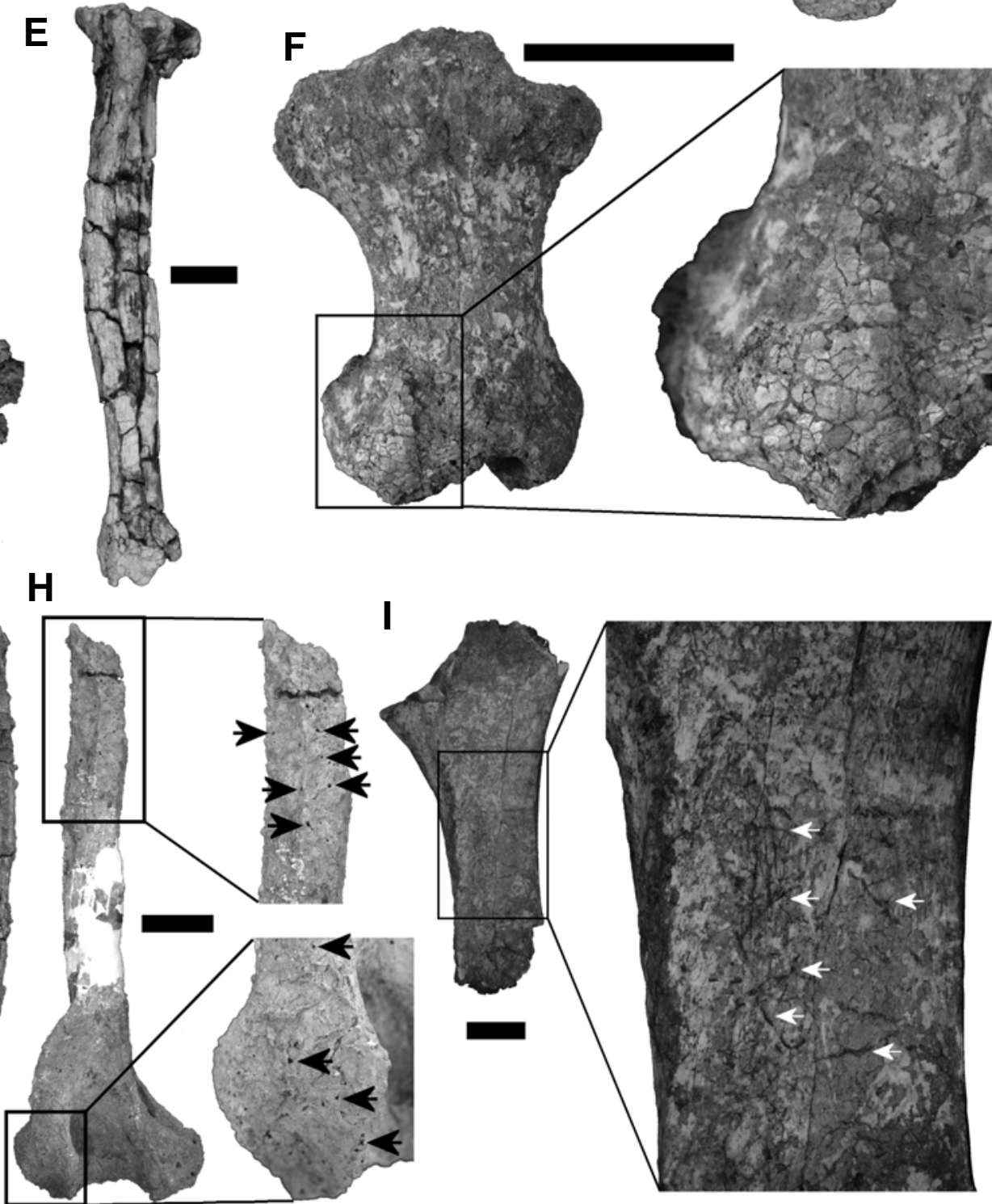

Figure 3. Fossils from Campanha. A, tibia of a mylodontid sloth (MCN-PV3229) with stage 1 (white arrows) and stage 2 (dark arrows) crackings; B, right dentary of Hemiauchenia sp. (MCN-PV1471) showing different patterns of cracking between bone and teeth; C, vertebra of Macrauchenia sp. (MCN-PV2160) with carbonate coating; D, osteoderms of Pampatherium sp. (top) and a mylodontid sloth (MCN-PV1944), kept together by carbonate coating; E, tibia of Palaeolama sp. (MCN-PV1975d) fractured due to carbonate expansion; F, tibia of a mylodontid (MCN-PV1482) with reticulate crackings; G, antler of a cervid (MCN-PV3256) with root casts and vertebrae of an ursid (MCN-PV1940) with root tubules (indicated by the arrow), formed by calcium carbonate; H, humerus of an ursid (MCN-PV1940) with insect borings (indicated by arrows); I, ulna of a ground sloth (MCN-PV0942) with root traces (indicated by arrows). Scale bars $=5 \mathrm{~cm}$. 
Table 1. List of the taxa analyzed for this work; several specimens could be identified only to the level of family. Abbreviations: CA, Campanha; CC, Chuí Creek; CS, continental shelf.

\begin{tabular}{l} 
Superorder XENARTHRA Cope, 1889 \\
\hline Order PILOSA Flower, 1883 \\
Family MEGATHERIDAE Owen, 1843 \\
Megatherium? Cuvier, 1796 \\
Family MYLODONTIDAE Gill, 1872 \\
Glossotherium Gervais, 1855 \\
Lestodon Gervais, 1855 \\
Mylodon Owen, 1839 \\
Catonyx Ameghino, 1891
\end{tabular}

Order CINGULATA Illiger, 1881

Family DASYPODIDAE Bonaparte, 1838

Propraopus Ameghino, 1881

Family PAMPATHERIIDAE Paula Couto, 1954

Holmesina Simpson, 1930

Pampatherium Ameghino, 1875

Family GLYPTODONTIDAE Burmeister, 1879

Doedicurus Burmeister, 1874

Glyptodon Owen, 1845

Panochthus Burmeister, 1872

Neuryurus Ameghino, 1889

Order LITOPTERNA Ameghino, 1889

Family MACRAUCHENIIDAE Gervais, 1855

Macrauchenia Owen, 1838

$\mathrm{X}$

Order NOTOUNGULATA Roth, 1903

Family TOXODONTIDAE Owen, 1845

Toxodon Owen, 1838

Order CARNIVORA Bowdich, 1821

Family URSIDAE Fischer de Waldheim, 1817 cf. Arctotherium

$\mathrm{X}$

Order URANOTHERIA McKenna \& Bell, 1997

Family GOMPHOTHERIIDAE Hay, 1922

Stegomastodon Pohlig, 1912

Order PERISSODACTYLA Owen, 1848

Family EQUIDAE Gray, 1821

Equus Linnaeus, 1758

Hippidion Owen, 1869

Order ARTIODACTYLA Owen, 1848

Family CAMELIDAE Gray, 1821

Hemiauchenia Gervais \& Ameghino, 1880

Palaeolama Gervais, 1867

Family CERVIDAE Goldfuss, 1820

Antifer Ameghino, 1889

Morenelaphus Carette, 1922 secondary channel, so its exact place of origin is not known. Ten specimens have their surface partially covered by crusts of sand grains cemented by iron oxide.

\section{Fossils from the continental shelf}

Most of the remains from the shelf were collected in the fossil concentrations along the beach in the southern portion of the CPRS (Concheiros). The predominant taxa are large-bodied herbivores (Table 1), and although rodents and carnivores have been described from these concentration (Rodrigues \& Ferigolo, 2004; Rodrigues et al., 2004), these were absent from the studied specimens.

All fossils are disarticulated; the most abundant skeletal elements belong to Voorhies' group I (192 specimens), followed by 30 that belong to group II, 28 to group III and 5 that could not be assigned to any of these groups (Table 2); 121 specimens are complete, 86 incomplete and 48 are fragments. These relative proportions are somewhat biased because fossil collecting is aimed at well-preserved or identifiable specimens; direct observation indicate that the total amount of small, unidentifiable fragments in the Concheiros is much larger than this (Lopes \& Buchmann, 2010; Aires \& Lopes, 2012).

Most of the complete (119) and incomplete (84) specimens belong to Voorhies' group I, whereas fragments include six specimens belonging to group I, 20 to group II and 20 to group III. Most of the specimens (209) do not exhibit signs of weathering; 38 exhibit shallow crackings (weathering stage 1) and 8 exhibit deeper crackings (weathering stage 2, Figure 5A). The higher proportion of fossils that exhibit weathering stages 1 and 2 belong to Voorhies' group II (22 and 6 specimens, respectively), whereas most of the unweathered remains (175) belong to group I. In long bones, the crackings produced by weathering are parallel to the longitudinal axis, whereas in curved surfaces such as acetabula and heads of femora the crackings exhibit a reticulate pattern (Figure 5B)

All fossils from the continental shelf are abraded, with 100 classified as grade 1 and 155 as grade 2. Most of the remains with abrasion grades 1 and 2 belong to Voorhies' group I (79 specimens) and group III (112 specimens), respectively. In fossil that belong to group II (6 of grade 1 and 26 of grade 2) the signs of abrasion are more concentrated at the epiphyses and protuberances (Figure 5C). The high grade of abrasion seen in many fossils obliterated morphological features that could provide taxonomic diagnosis (Figure 5D). Teeth are less abraded in comparison to bones.

No signs of biogenic activities such as predation, scavenging, or insect nesting were observed, but the few remains collected at greater depths by fishing vessels exhibit bioincrustation by marine organisms such as oysters, corals, sponges and bryozoans. One humerus of Toxodon and a fragment of an incisor of Notiomastodon exhibit borings produced by mytilid bivalves (Lopes \& Buchmann, 2010; Lopes, 2012). Several specimens have their external surface partially covered or internal cavities filled up with rocky material (Figure 5E). This material is composed of sand grains cemented by calcium carbonate (calcite), but shell fragments are also cemented in the rock matrix. 

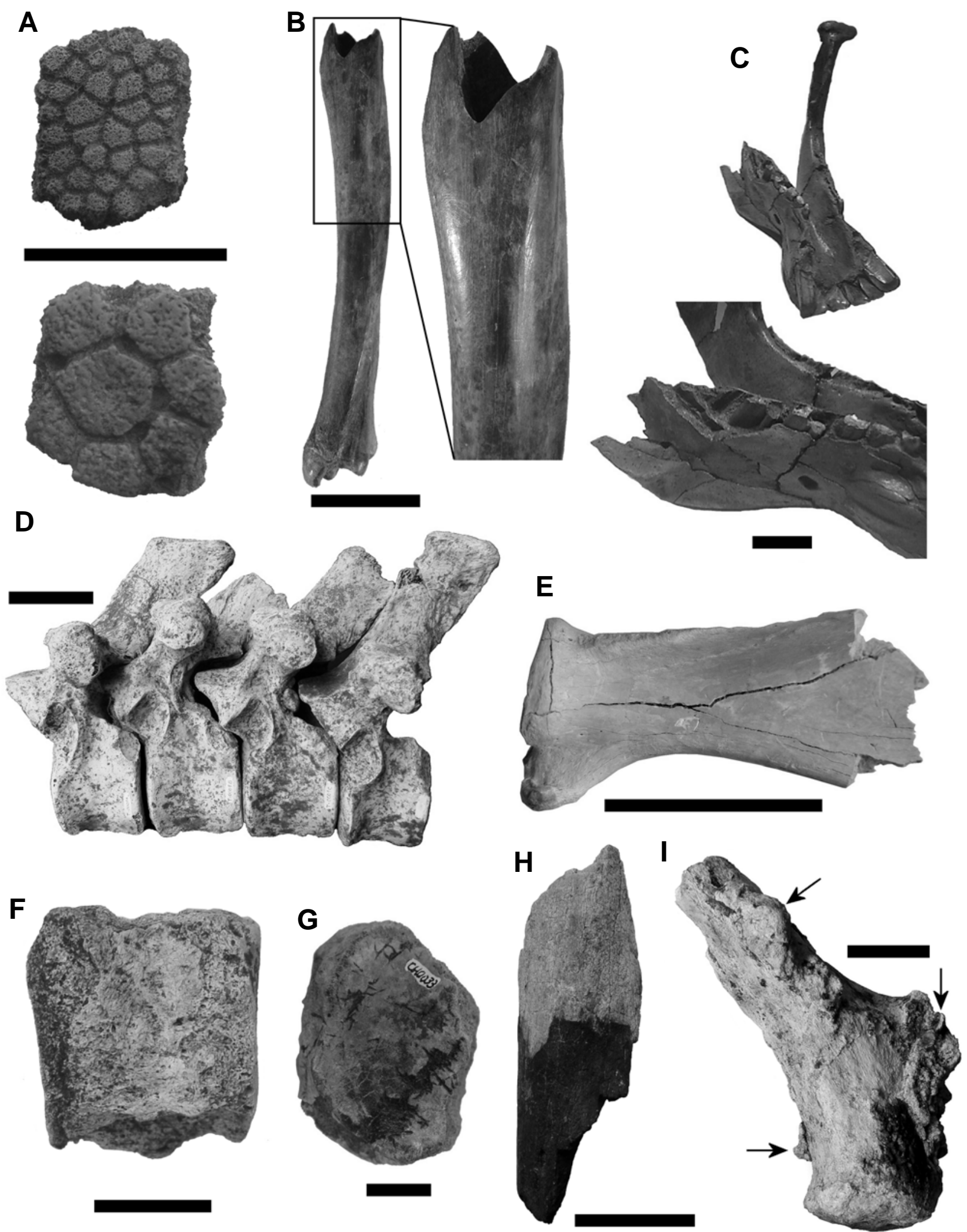

Figure 4. Fossils from Chuí Creek. A, complete osteoderms of Panochthus sp. (LGP-P0022, on top) and Glyptodon sp. (LGP-P0005); B, tibia of a cervid (LGP-10001) with its proximal end exhibiting pre-fossilization fracture; C, jaw of Toxodon sp. (LGP-E0003) with crackings produced by sediment overload; D, articulated thoracic vertebrae of a mylodontid sloth (LGP-Q0001); E, scapula of a cervid with crackings indicating weathering stage 2; F, vertebral body (LGP-CH0157) in lateral view, showing the internal spongy structure exposed due to abrasion (stage 2); G, unciform bone (LGP-CH0033) with root traces; $\mathbf{H}$, fragment of a long bone (LGP-CHO080) darkened due to partial exposure to water; I, antler of Morenelaphus sp. (LGP-I0005) with carbonate coatings indicated by arrows. Scale bars $=5 \mathrm{~cm}$. 
Table 2. Total number of skeletal elements from each assemblage, divided according to Voorhies'groups. Abbreviations: CA, Campanha; CC, Chuí Creek; CS, continental shelf; NI, unidentified.

\begin{tabular}{|c|c|c|c|c|}
\hline & & $\mathrm{CA}$ & CC & $\mathrm{CS}$ \\
\hline \multirow{10}{*}{ 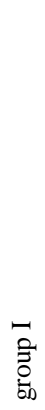 } & vertebra & 30 & 37 & 11 \\
\hline & sternum & 0 & 1 & 0 \\
\hline & sacrum & 6 & 6 & 0 \\
\hline & Rib & 25 & 30 & 0 \\
\hline & metapodial & 11 & 3 & 2 \\
\hline & carpus & 4 & 7 & 0 \\
\hline & tarsus & 0 & 4 & 37 \\
\hline & phalanx & 0 & 5 & 13 \\
\hline & osteoderm & 92 & 52 & 127 \\
\hline & scapula & 1 & 5 & 2 \\
\hline \multirow{5}{*}{ 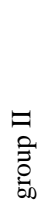 } & humerus & 6 & 9 & 1 \\
\hline & ulna & 6 & 3 & 2 \\
\hline & radius & 4 & 2 & 3 \\
\hline & femur & 14 & 0 & 5 \\
\hline & tibia & 9 & 2 & 19 \\
\hline \multirow{6}{*}{$\begin{array}{l}\Xi \\
\text { 号 } \\
\text { ठ․ }\end{array}$} & antler & 2 & 9 & 0 \\
\hline & skull & 2 & 4 & 2 \\
\hline & Jaw & 9 & 3 & 4 \\
\hline & tooth & 8 & 18 & 22 \\
\hline & NI & 12 & 66 & 5 \\
\hline & Total & 241 & 266 & 255 \\
\hline
\end{tabular}

The specimens from the continental shelf are remarkably different from remains collected in continental sites, owing to their higher mechanical resistance and color (Lopes et al., 2008). In general, all these remains are dark-colored, but exhibit a range of variation from ochre to black, and many specimens are reddish. In some broken and abraded specimens, the exposed internal surfaces exhibit different colour (usually lighter) in comparison to the outer surface of the bone (Figure 5F). Some fossils, including a molar of a Scelidotheriinae sloth (Lopes \& Pereira, 2010), and a distal end of a humerus (Figure 5G), exhibit shallow and irregular dendritic grooves on the surface.

\section{EDX analyses}

The results of this analysis (Table 3) show that all fossil samples still contain a significant proportion of the elements (calcium and phosphorus) that composed the original bones, despite of the reduction of some $10 \%$ in the calcium content of the fossils in comparison to recent bones. A major difference is the higher iron content (between $\sim 2$ and $\sim 5 \%$ ) in the fossils than in recent bones (less than 1\%). The fossil osteoderm with higher iron content (LGP-N0217) exhibits reddish color, whereas the other osteoderm (LGP-N0218) has lower iron content and is black-colored.

The fossil with the highest iron content ( 5\%) is the one from Chuí Creek, which is light pink-colored. As seen in the armadillo remains, manganese, barium and sulphur are not present in the recent bone but occur in the fossils, whereas strontium was found only in the recent specimen. Both fossil and recent specimens do not contain scandium, titanium or yttrium. Copper and silicon are the only elements found in this fossil that are not present in the fossils from the shelf, but it also contains zinc and zirconium just like the recent armadillo specimen.

\section{DISCUSSION}

The numerical results of the analyzed specimens from the three areas were converted to percentages and plotted in graphics (Figure 6) to compare the distribution of post mortem modifications between the assemblages.

An important caveat must be made here, except for the material from Chuí Creek. Most of the specimens are from preexistent collections and do not have details concerning the depositional setting (such as the type of sedimentary matrix, azimuth, vertical orientation, association with other remains) or do not have a precise depositional setting (the specimens from the continental shelf have been reworked and transported several times). Therefore, inferences and conclusions regarding the taphonomic history of these remains are incomplete and somewhat biased. Nevertheless, the results presented here can serve as a basis for analysis and comparison with remains obtained through detailed collecting.

In all three assemblages large-sized herbivores (body mass $\geq 100 \mathrm{~kg}$, following Fariña et al., 1998) are the most abundant taxa (42\%), followed by medium-sized taxa (21,8\%); no small-sized taxa were identified, and 36,2\% of the material could not be assigned to any specific group. Although rodents have been found in the Campanha (Kerber \& Ribeiro, 2011; Kerber et al., 2012), Chuí Creek (Ubilla et al., 2008; Kerber et al., 2011b; Pereira et al., 2012) and continental shelf (Rodrigues \& Ferigolo, 2004), these are very scarce. Considering the large amount of incomplete and fragmented specimens found in the three assemblages, this pattern probably represents a taphonomic bias towards large-bodied taxa, reflecting the preferential destruction of small-sized remains. The absence of carnivores probably results from a combination of the small size of these animals in comparison to the herbivores and the low species richness of this group in the Pleistocene of South America (Prevosti \& Vizcaíno, 2006; Aires \& Lopes, 2012).

\section{Representativity of skeletal elements}

In the three assemblages, the most abundant skeletal elements are those of Voorhies'group I. Most of these are osteoderms of cingulate xenarthrans (Table 2), which are present in large numbers in each individual; besides, these are small-sized and compact in shape, which allows a quick burial and therefore higher preservation potential than larger elements. The scarcity of the sternal bones, sacrum, carpus and scapula in the three assemblages may result from the small size or fragility, which makes these elements more prone to mechanical destruction and abrasion. The larger proportion of tarsal elements from the shelf consists of astragali of giant sloths and cervids. The role played by hydraulic sorting is not clear, but it may be responsible for 

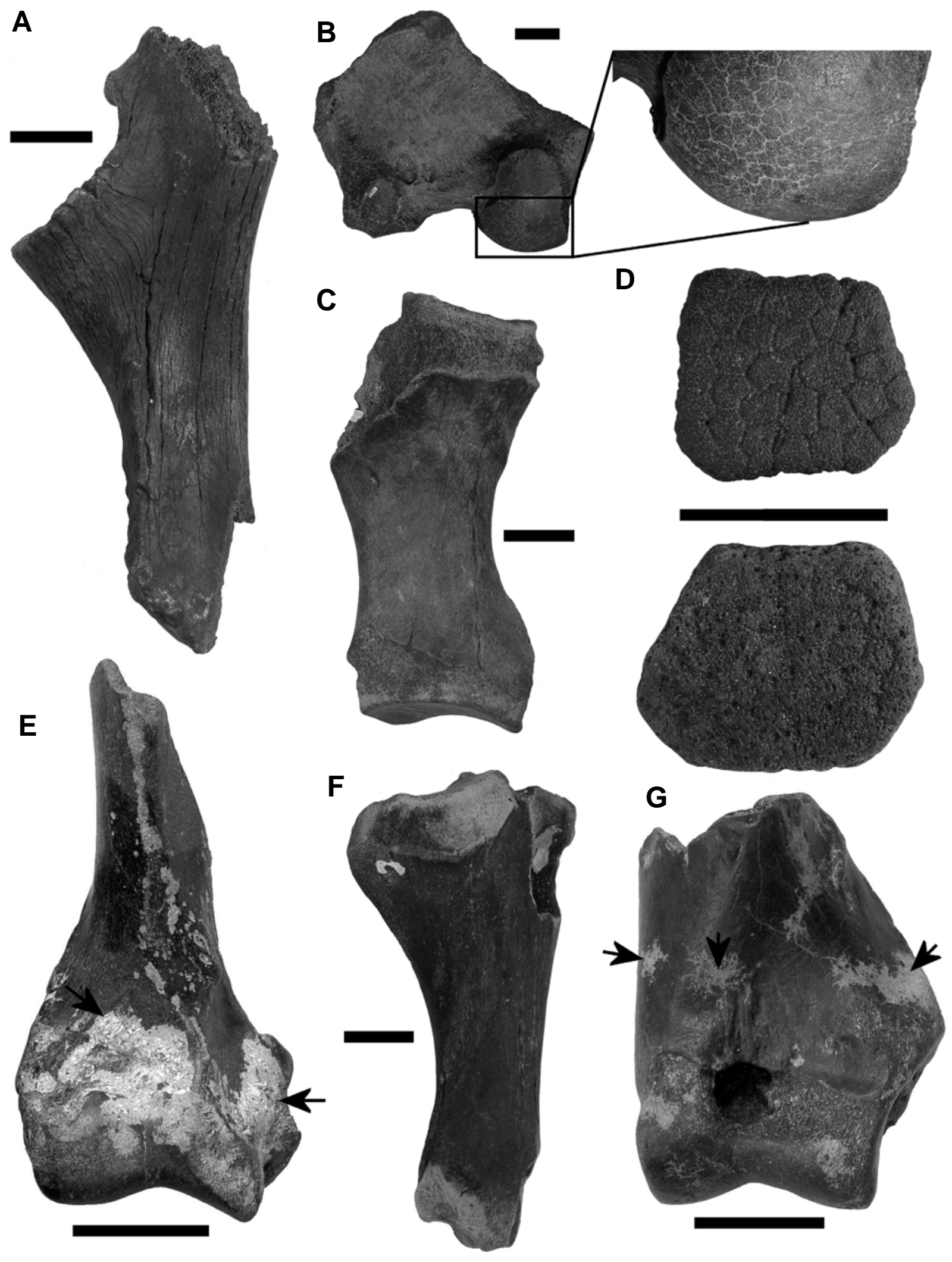

Figure 5. Fossils from the continental shelf. A, incomplete ulna (LGP-PC0205) with deep crackings (weathering stage 2); B, distal end of a megatheriid femur (LGP-R0006) with reticulate crackings on the lateral condyle; C, incomplete tibia of a mylodontid sloth (LGP-Q0006) with stage 2 abrasion on its extremities; D, two osteoderms of Panochthus sp. (LGP-P0099 and 0221), showing different degrees of abrasion; E, partial humerus of Smilodon sp. (LGP-U0002) with crusts of beach rock on the distal end (indicated by arrows); F, incomplete tibia (LGP-PC0046) with light-colored abraded surfaces; G, fragment of a humerus (LGP-PC0206) with shallow, irregular grooves possibly produced by plant roots or algae (indicated by arrows). Scale bars $=5 \mathrm{~cm}$. 
Table 3. Percentage of metals and oxides found in fossil and recent specimens using EDX. Abbreviation: nd, means not detected.

\begin{tabular}{|c|c|c|c|c|c|}
\hline \multirow[b]{2}{*}{ Metals } & \multicolumn{3}{|c|}{ Osteoderms } & \multicolumn{2}{|c|}{ Bones } \\
\hline & Recent & N0217 & N0218 & Recent & Fossil \\
\hline $\mathrm{Ca}$ & 84.385 & 75.108 & 76.621 & 84.881 & 75.227 \\
\hline $\mathrm{P}$ & 14.617 & 14.850 & 15.678 & 14.794 & 13.923 \\
\hline $\mathrm{Fe}$ & 0.729 & 4.492 & 2.185 & 0.101 & 5.004 \\
\hline Mn & nd & 1.466 & 1.548 & nd & 2.222 \\
\hline $\mathrm{Ba}$ & nd & nd & 1.453 & nd & 0.702 \\
\hline S & nd & 0.355 & nd & nd & 0.379 \\
\hline Sc & nd & 1.466 & 1.345 & nd & nd \\
\hline $\mathrm{Si}$ & nd & nd & nd & nd & 1.778 \\
\hline $\mathrm{Sr}$ & 0.175 & 1.068 & 1.056 & 0.118 & nd \\
\hline $\mathrm{Ti}$ & nd & 1.219 & nd & nd & nd \\
\hline $\mathrm{Y}$ & nd & nd & 0.114 & nd & nd \\
\hline $\mathrm{Cu}$ & nd & nd & nd & nd & 0.106 \\
\hline $\mathrm{Zn}$ & 0.083 & nd & nd & 0.106 & 0.102 \\
\hline $\mathrm{Zr}$ & 0.011 & nd & nd & nd & 0.021 \\
\hline
\end{tabular}

the relative absence of tarsal elements and phalanges in the Campanha and Chuí Creek.

The relative proportion of elements that belong to Voorhies'group II are somewhat similar between the assemblages, except for a higher abundance of femora from the Campanha and tibiae from the continental shelf. The relative absence of long bones (except for humeri) in Chuí Creek in comparison to the other assemblages could be related to sorting by transportation, but the lack of signs of long-term transportation (e.g. abrasion) suggests that other mechanisms may be involved. Weathering (see below) could contribute for the under-representation of those elements, but the action of carnivores is also a possible explanation, despite the lack of other evidence. Carnivores (both predators and scavengers) remove preferentially the limb elements, which contain considerable amounts of meat and marrow-rich bones; the parts can be transported to the carnivores' dens, where the resulting bone accumulation consists of fragmented remains with abundant gnawing marks (D’Andrea \& Gotthardt, 1984; Blumenschine, 1986; Binford et al., 1988; Palmqvist \& Arribas, 2001).

In the three assemblages, the elements that belong to Voorhies' group III are mostly isolated teeth, typically numerous per individual and resistant to mechanical destruction. No complete skulls were present in the analyzed specimens, which probably results from their fragility, whereas jaws (either complete or as isolated dentaries) are more resistant in comparison and thus are more likely to be preserved (Voorhies, 1969). In the three assemblages, jaw elements are more numerous and better preserved than skull elements, despite of being mostly incomplete.

The presence in the three assemblages of remains belonging to all Voorhies'groups suggests that these are attritional assemblages (Behrensmeyer, 1982), rather than being formed by carnivores or selective removal of certain elements by hydraulic sorting.

\section{Physical integrity}

The mechanical resistance of bones is a function of both the microstructure of the bone tissues and the macrostructure of the different skeletal elements (Martill, 1992). The fractures in bones, defined as discontinuities in the bone structure, are produced by external stresses that exceed its elasticity or resistance and include flexion, rotation, compression, shearing and traction (Aufderheide \& Rodriguez-Martín, 1998). Some mechanisms that can cause fractures prior to death or fossilization are predation, scavenging, intra- and interspecific combat, and accidents; fossilized bones may be fractured by erosion, transportation or trampling by other animals.

Most of the remains from the Campanha and continental shelf are complete, whereas those from Chuí Creek are mostly fragments. In the three assemblages, the largest amount of complete fossils belong to the Voorhies' group I (mostly osteoderms and tarsals); these elements are compact, small and more numerous than other skeletal parts, thus are more likely to be represented in the fossil record. In all three assemblages, skeletal elements that belong to Voorhies' groups II and III are mostly incomplete or fragmented, owing to the lower robustness of these elements in comparison to the compact elements of group I (Voorhies, 1969) and to their larger size, which requires high rates of sediment deposition to completely cover the bones and prevent further mechanical destruction.

All broken fossils exhibit plain fractures, in most cases transverse to the major axis of the bone, indicating that were subject to reworking after fossilization, possibly by multiple climate-driven cycles of increased fluvial activity. If the breaking resulted from crackings produced by weathering, then the bones would be splitted along the major axis (Behrensmeyer, 1978). The jaw of Toxodon (Figure 4C) was excavated from the bank of the creek, and was found lying on its left side (Lopes et al., 2001). This specimen had most of its right ascending ramus eroded away, and the left and horizontal rami exhibit plain fractures. The rami are very 

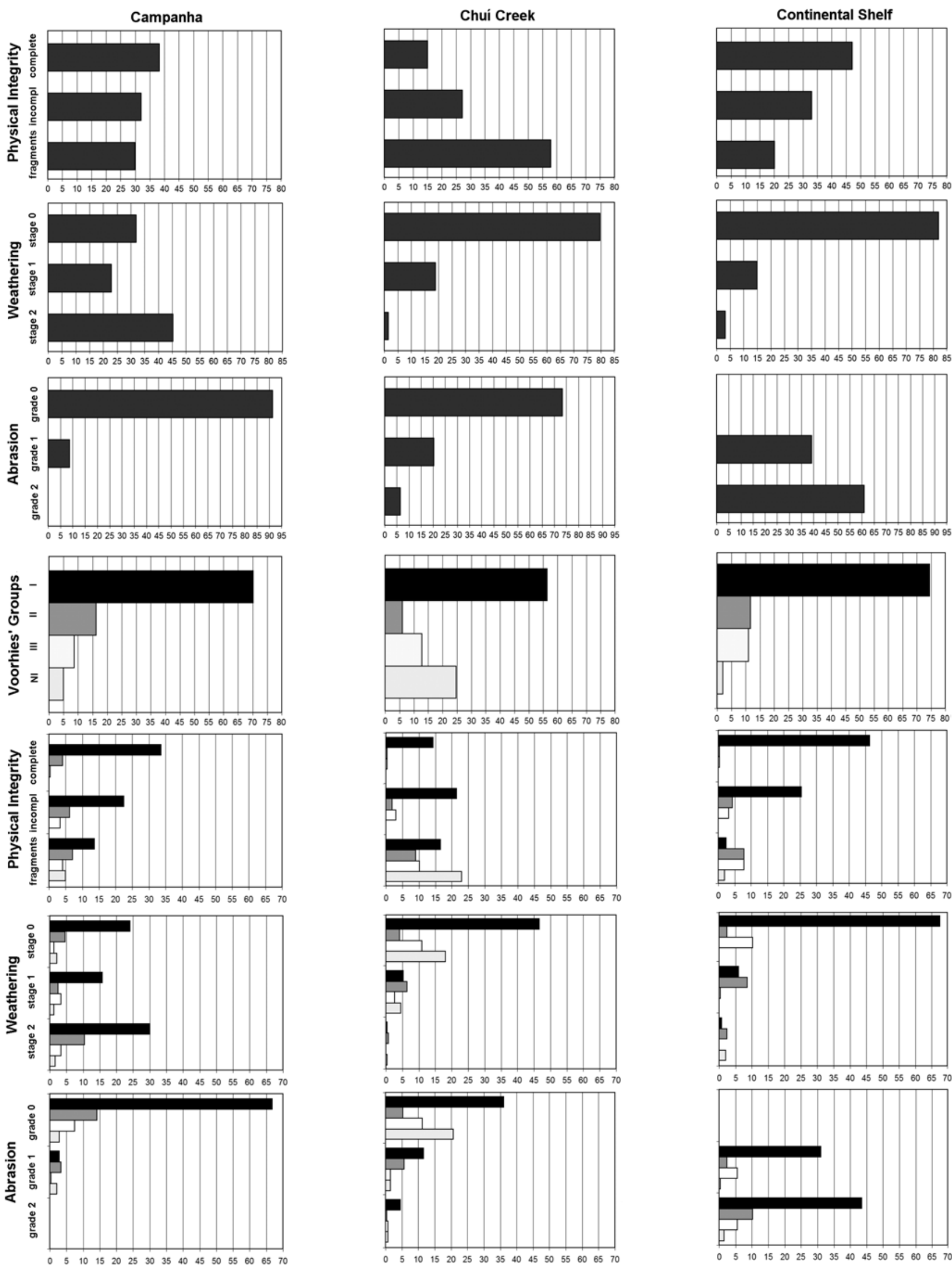

Figure 6. Graphics comparing the results (in percentages) of the analyzed parameters for the three assemblages; the upper graphics represent the total of specimens, while in the lower the results are divided according to the Voorhies'groups. Abbreviation: NI, unidentified elements. 
thin, therefore if these fractures resulted from weathering or transport, the specimen would have not been preserved as a whole; the most likely explanation is that these fractures result from post-burial sediment overload.

The only specimen conclusively fractured prior to fossilization is the cervid tibia from Chuí Creek (Figure 4B). The absence of deep crackings produced by weathering, however, suggests that a predator or scavenger could have broken this specimen to extract the marrow, or it was subject to trampling before the final burial. Observations in modern ecosystems show that carnivores tend to take away the body parts for consumption, which produces bones that are very fragmented and exhibit gnawing marks (D'Andrea \& Gotthardt, 1984; Blumenschine, 1986; Binford et al., 1988). Although the tibia exhibits parallel scratches on its surface, these are too shallow to have been produced by gnawing, even by small rodents (Haynes, 1980, 1983; Klippel \& Synstelien, 2007); perhaps these signs result from friction between the bone and the substrate during transportation.

The fossil-bearing fluvial facies exposed along the banks of Chuí Creek indicates that the paleo-fluvial systems were shallow ( $<1 \mathrm{~m}$ ), implying that large carcasses would remain exposed for relatively long periods prior to burial. During this interval, the bones would have been subject to the action of carnivores and to weathering after decomposition of the soft tissues. The large amount of fragmented fossils in the Chuí Creek assemblage indicates that these remains were subject to at least one cycle of burial-fossilization-reworking-burial, which could be related to climate-driven cycles of increaseddecreased fluvial activity. Studies in speleothems from southern Brazil revealed that episodes of higher precipitation (which controls fluvial discharge) during the late Pleistocene occurred in precession-driven insolation cycles of $21 \mathrm{ka}$ (Cruz Jr. et al., 2005).

\section{Weathering}

Weathering in bones is evidenced by the presence of crackings caused by exposure to variations in local environmental conditions, mainly temperature and moisture (Behrensmeyer, 1978). This process consists in the separation and destruction of organic and inorganic phases of the bones by chemical and physical agents, acting either directly on the remains or on the surrounding sediments. It is likely to be caused by degradation of collagen fibers by UV radiation, given that bones that remain protected from direct sunlight (by trees or soft tissues) and parts of the bones that remain in contact with the soil do not develop such features (Tuross et al., 1989). The crackings are also produced by crystallization of salts in alkaline soils, and the time interval between the exposure of the bones and the appearance of crackings varies among different environments, such as temperate and tropical forests and savannas (Behrensmeyer, 1978; Tappen, 1994; Janjua \& Rogers, 2008). While crackings develop on bones following the orientation of collagen fibers, in teeth the crackings may develop in an irregular, reticulate pattern (Figure 7), or develop cracks that may cause the teeth to split longitudinally (Behrensmeyer, 1978).

Although the weathering signs are based on the six stages described by Behrensmeyer (1978), there are some differences. The stage 1 presented here roughly corresponds to the stages 1-2 described by that author, whereas stage 2 corresponds to the stages 3-4; no fossil was classified beyond this, either because the remains were destroyed after reaching stage 3, or they did not reach more advanced stages. In specimens from Chuí Creek and the continental shelf, most of the remains are unweathered (stage 0 ), whereas among those from the Touro Passo Formation stages 0 and 2 are the most common. In all three areas the largest proportion of stage 0 remains are those that belong to Voorhies' Group I. This

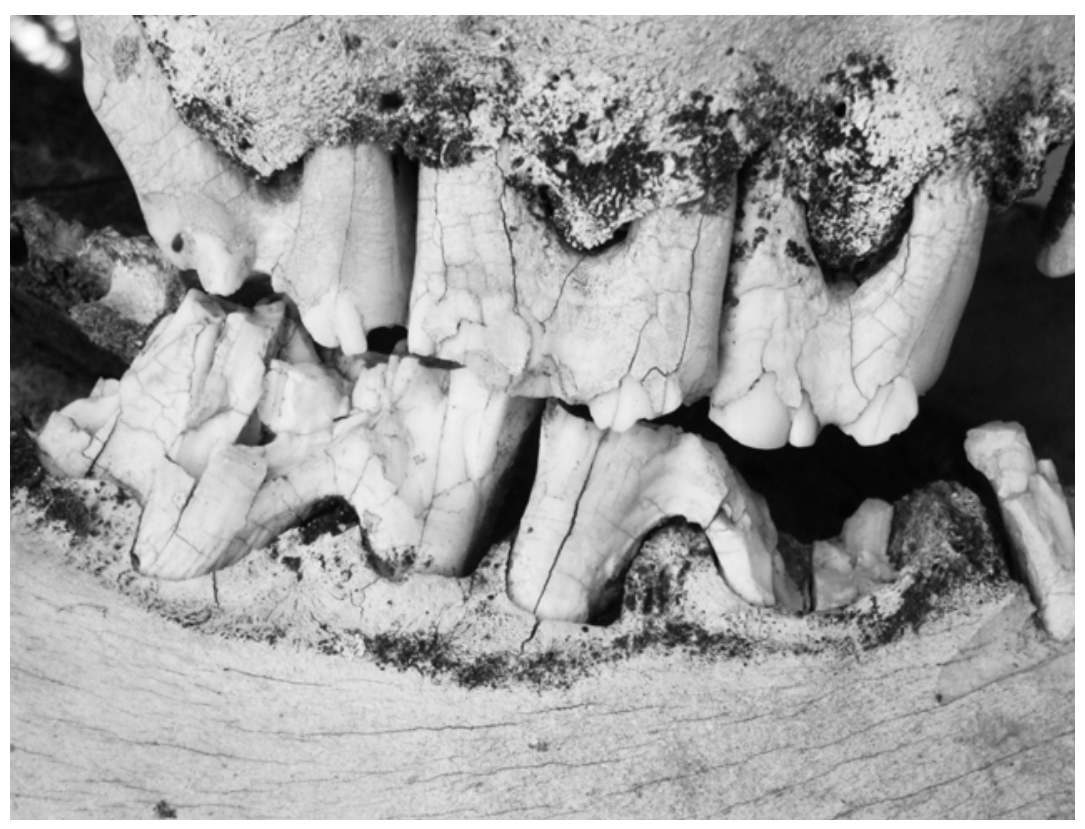

Figure 7. Detail of the skull of a modern cow showing the difference in weathering signs on teeth and bone. 
pattern is likely to be related to the small size of these bones, that makes them prone to quick burial after decomposition of the soft parts, even under low rates of sediment deposition.

Most of the remains from the Campanha classified as stage 1 belong to the Voorhies' group I, whereas the larger proportion of stage 1 remains from Chuí Creek and the continental shelf belong to group II. These elements are larger and should have been covered by sediment or water shortly after death or decomposition of the soft parts in order to be protected from weathering. Although a precise estimate of how long these remains were exposed before burial is difficult, because weathering stages may develop at different periods owing to different local conditions, modern bones may take periods of four years or more to develop weathering stage 3-4 (Behrensmeyer, 1978).

Among the remains from the Campanha, most of the fossils classified as stage 2 also belong to Voorhies' group I; although few remains from Chuí Creek and the continental shelf were classified as stage 2 , most consist of specimens that belong to group II. The latter are relatively large bones that can remain exposed for long periods before the final burial, so that are more likely to reach advanced weathering stages, and can even be completely destroyed as a result of this process; this could have contributed for their relative absence in the Chuí Creek assemblage.

In the Touro Passo Formation, the fossil-bearing Muddy Member consists of silty clay with small sand lenses and abundant calcium carbonate concretions, features that suggest deposition in floodplains (Bombin, 1976; Bombin \& Klamt, 1975). If this fluvial system was subject to cyclic climate-driven oscillations, it is possible that the remains would be deposited by flooding, and become exposed to weathering; in the following cycle the surviving remains could have been buried, and subject to carbonate precipitation when the water retreated. In fact, about $70 \%$ of the specimens from Touro Passo that were classified as stage 2 also exhibit carbonate crusts or cavities filled up by calcium carbonate. The presence of both longitudinal and transverse crackings in carbonate-bearing specimens (see Figures 3E-G) suggests that carbonate precipitation and posterior expansion due to recrystallization may be responsible for the reticulate cracking pattern in these specimens.

\section{Abrasion}

The main cause of mechanical destruction of bones in shallow waters is abrasion (Brett \& Baird, 1986). The surface abrasion in bones results from the friction of the bone against the substrate and/or the sediment in suspension in water during transportation. Therefore, it indicates the duration and intensity of the interaction between the bone and the sediment, but not necessarily the distance of transportation, because bones are transported for several kilometers without becoming abraded even for periods of ten years or more (Behrensmeyer, 1982; Aslan \& Behrensmeyer, 1996); fossilized bones are more prone to abrasion than fresh bones (Fernández-Jalvo \& Andrews, 1992). Mechanical abrasion results in rounded edges and removal of the external layers of bones, exposing the internal spongy structure. The removal of cortical bone by abrasion may be misinterpreted as signs of erosion related to osteoarthrosis, which can be caused by diseases, old age or overweight (Ferigolo, 1992, 2007). These, however, are more concentrated at articular margins and surfaces and in vertebrae, and differ from abrasion by the presence of surrounding bony ridges (marginal osteophytes) and undercut edges (Ferigolo, 1992; Waldron, 2011).

The lower proportion of abraded remains in the Chuí Creek and Campanha assemblages in comparison to the continental shelf assemblage indicates that the former were not subject to long-term transportation, despite of the large number of incomplete bones and fragments. The unabraded remains (grade 0) from the Campanha and Chuí Creek are mostly elements that belong to the Voorhies' group I; among the specimens from the continental shelf, however, these are the most abraded. This difference probably results from the hydraulic regime experienced by these remains: because the elements of group I are easily transported by waves and currents, which dominate shallow marine settings, these are likely to be continuously moved as sedimentary particles, subject to friction against the bottom and sand in suspension. Once broken, these remains will have their volume reduced and a larger surface exposed to abrasive agents therefore will soon result in small-sized unidentifiable fragments; this would explain the scarcity of small elements of Voorhies' group I (such as carpals and sternal bones) among the samples from the continental shelf.

The smaller and more compact elements of Voorhies' group I (osteoderms, tarsals, phalanges) exhibit signs of abrasion all over their surfaces. In vertebral centra, abrasion is mostly absent in the cranial and caudal surfaces, but the dorsal, ventral and lateral surfaces are usually abraded (Figure 8), because these elements tend to roll on due to their cylindrical shape under either unidirectional or bidirectional water flow (Behrensmeyer, 1991). In long bones of the Voorhies' group II, the abrasion is more concentrated in the proximal and distal ends, because these elements tend to rest with the major axis aligned with unidirectional currents, or perpendicular to bidirectional currents (Behrensmeyer, 1991). Besides, these bones usually have expanded proximal and distal epiphyses, which are in contact with the sediment more often than the shaft, further contributing for the observed pattern of abrasion.

\section{Other modifications}

Several biogenic agents, such as insects (Kaiser, 2000; Fejfar \& Kaiser, 2005; Rogers et al., 2007), predators/ scavengers (Haynes, 1980; Andrews \& Fernández-Jalvo, 1997; Domínguez-Rodrigo \& Piqueras, 2003; Andrés et al., 2011), plants (Montalvo, 2002), or humans (Selvaggio, 1994; Blumenschine et al., 1996; Defleur et al., 1999) can produce distinct marks on bones. Tooth marks are characterized by pits and grouped parallel sulci, more conspicuous in nasal bones, scapulae, distal ends of humeri, radii, femora and tibiae, iliac crest and pubic symphysis (Haynes, 1980; D’Andrea \& Gotthardt, 1984). Although it is possible to distinguish marks produced by scavengers / predators from those produced by 


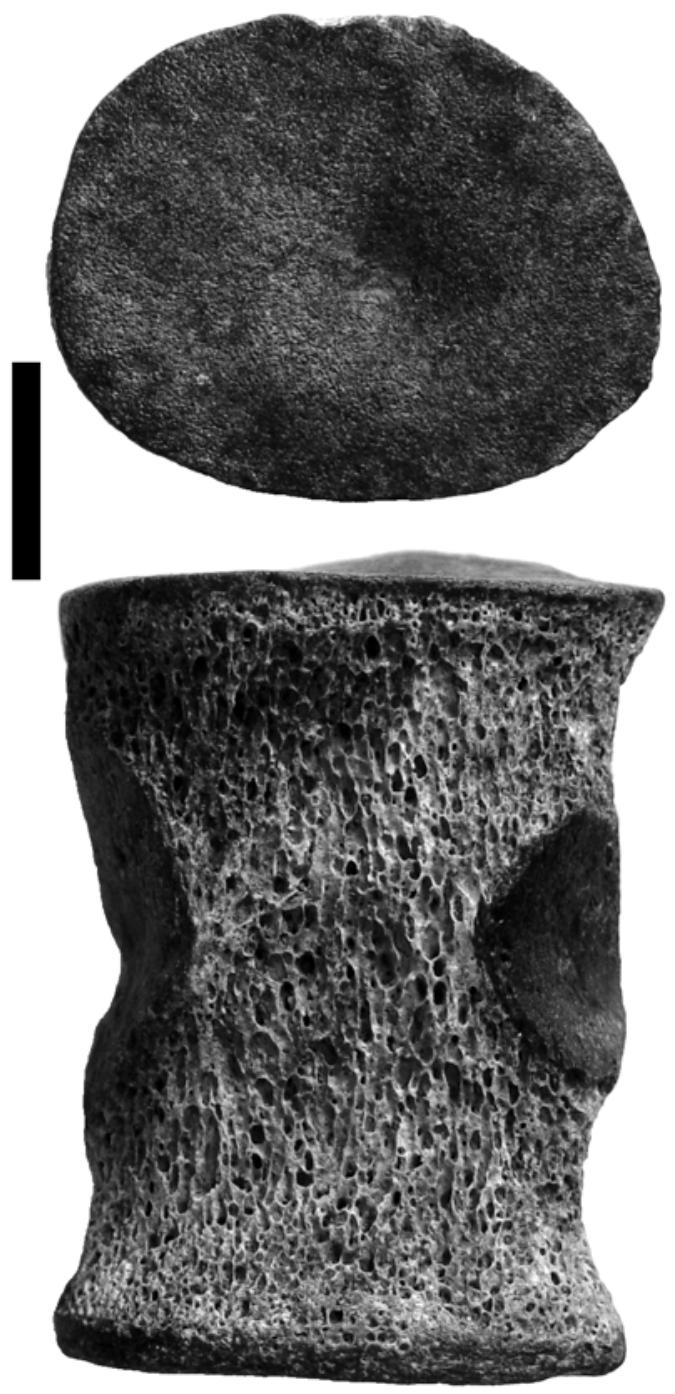

Figure 8. Vertebral centrum (LGP-PC243) in cranial and ventral views, showing differential abrasion between the cranial/caudal (top) and lateral surfaces. Scale bar $=20 \mathrm{~mm}$.

humans (Blumenschine et al., 1996), tooth marks usually do not allow to identify at the level of species the organism that produced them, unless the intraspecific variation of dental morphology and geographic distribution of the organism are well known (Domínguez-Rodrigo \& Piqueras, 2003).

Other biotic agents that can produce modifications in bones are insects that use organic remains as food sources, habitat and reproduction. Beetles of the family Dermestidae are common in carcasses of recently dead animals but also in dry bones. Distinct species of this family can be found in carcasses at different seasons and stages of decomposition (Moura et al., 1997; Bharti \& Singh, 2003).

The three areas provided very few fossils with marks that could be attributed to biotic agents. The most remarkable example is the ursid ulna from the Campanha (Figure 3H), that exhibits small holes interconnected by chambers excavated inside the cortical bone, and also some Cubiculum chambers. The infestation by insect larvae could only be possible if the carcass remained exposed for some time on the surface, but the absence of weathering signs on these remains suggest that the bones were protected by meat and skin until the final burial.

The shallow dendritic grooves observed in the ground sloth ulna from the Campanha (3I), in some fossils from Chuí Creek (Figure 4G), and in sloth teeth from the continental shelf (Lopes \& Pereira, 2010), probably result from dissolution by acids produced by decaying fungi or plant roots that grew directly on the bone while these remains were exposed on the surface or were buried near the surface, within the reach of the roots. Traces like these are classified as Sphenoichnia (Montalvo, 2002).

The presence of calcium carbonate concretions is a feature observed mostly on fossils from the Touro Passo Formation. The fossil-rich horizon of this unit (Muddy Member) also exhibits the carbonate concretions correlated to those found in the CPRS (Bombin \& Klamt, 1975). The carbonate found in the fossils occurs mostly as crusts, but rhizoconcretions and root tubules (sensu Klappa, 1980) were also observed. This indicates that the fossils were buried within the vadose zone, where carbonate is concentrated due to high evaporation rates under dry (mean annual precipitation equal or less than 500 mm/year) climates (Bombin \& Klamt, 1975; Kholodov, 2007). The ages of the fossils from the Touro Passo Formation and Chuí Creek, and organic matter-rich sediments that overlie the caliche of the CPRS, suggest that this carbonate horizon was formed during the last glaciation, between 34 and $10 \mathrm{ka}$ BP (Lopes et al., 2010, 2014; Kerber et al., 2011; Lima et al., 2013), therefore under dry and cold climate.

Crusts of sand grains cemented by iron were found only in fossils from Chuí Creek. This material indicates seasonal, warm and humid climate conditions compatible with tropical and subtropical climate; under these conditions, weathering and pedogenesis tend to produce soils enriched in iron and aluminum hydrates and oxides within the vadose zone through the process of laterization (Maignien, 1966).

The crusts found in fossils from the continental shelf, formed by sand grains and shells cemented together are of marine origin (beach rock). This material consist of sand grains and shells cemented by calcium carbonate precipitated in beach environment, under the influence of freshwater discharge and warm climate conditions (Branner, 1904; Russell \& McIntyre, 1965). Besides having paleoclimatic implications, because beach rock does not form in the coast of southern Brazil today, the association of fossils of terrestrial mammals with this material also reinforces the notion that these remains have been reworked multiple times, in response to sea-level advances during interglacial epochs (Lopes et al., 2008; Lopes \& Buchmann, 2010).

\section{EDX analysis}

The physical properties of the fossils from the continental shelf (most notably color and mechanical resistance) are so distinct than those from Chuí Creek and the Campanha, that the most likely explanation is the post burial diagenesis in marine environment. Either the incorporation of minor elements occurs by substitution of elements in the apatite 
crystalline structure, or by filling of minute pores and crackings in the structure of the fossil; being a highly porous and permeable material, bone has plenty of spaces to be filled up by other elements (Parker \& Toots, 1980). Besides, its crystallites are small and poorly crystalline, therefore provide sites for adsorption of many trace metals (Trueman \& Tuross, 2002). Strontium and yttrium are incorporated by substitution of calcium in the apatite crystals, while manganese, iron, zirconium and silicon occur as fillings, although silicon can also replace phosphorus in apatite crystals (Parker \& Toots, 1970). Trace elements can also be incorporated through the diet, and have been used for paleodietary reconstructions (Francalacci, 1989; Subirà \& Malgosa, 1992; Safont et al., 1998).

In many broken or highly abraded fossils from the continental shelf (more evident larger bones such as those of Voorhies'group II), the color along the broken margin and interior of the specimen is lighter than that of the outer surface. The broken margins show that the dark color does not reach deeply inside the bone (Figure 9), suggesting that the process of substitution or filling was incomplete, perhaps because of saturation of the pores by the incorporated material or to a change in the chemical conditions of the depositional environment.

The amounts of calcium and phosphorus found in the fossils are not much different from those found in recent bones. The small differences may indicate the substitution of apatite calcium and phosphorus by strontium and scandium in the osteoderms from the continental shelf. The amount of strontium is similar on both recent specimens, although large variations are expected among terrestrial vertebrates due to dietary differences; the concentrations of this element are higher in herbivores than in carnivores (Rheingold \& Hues, 1983; Francalacci, 1989). On the other hand, substitution of calcium by strontium occurs mostly during diagenesis rather than during lifetime (Trueman \& Tuross, 2002). Both fossil osteoderms exhibit about ten times more strontium than recent bones probably reflecting the higher concentration of this element in seawater, which also controls the amount of strontium found in fish bones (Parker \& Toots, 1970, 1980). The absence of strontium in the fossil from Chuí Creek also reinforces this interpretation.

The highest iron content (about 5\%) was found in the fossil from Chuí Creek, followed by the osteoderms from the continental shelf. The osteoderm N0217 has the highest iron content (about 4\%), and also exhibits reddish color, while osteoderm N0218, with only $2 \%$ of iron, is black, suggesting that the color variation among the specimens from the shelf is related to elements incorporated during diagenesis. On the other hand, barium and yttrium, which were detected only in osteoderm N0218, may have also contributed for its dark color. Although small amounts of yttrium can be assimilated through diet and incorporated into bone tissue (MacDonald et al., 1952), its presence only in one fossil osteoderm suggests that it is more likely related to diagenesis.

Iron is incorporated into fossils during diagenesis, occurring as fillings mostly in large cavities, such as

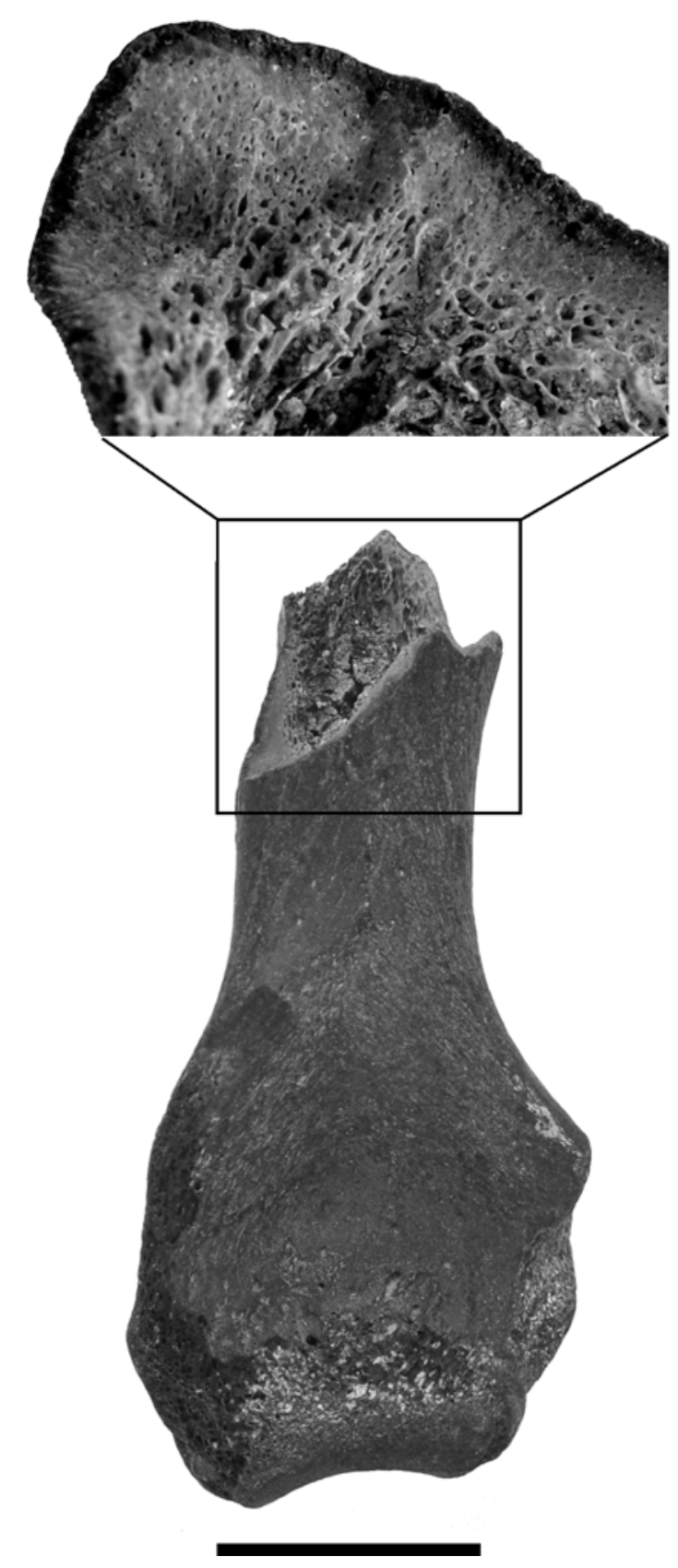

Figure 9. Unidentified humerus (LGP-PC241) broken at its proximal end, showing differences between the external color of the bone and the broken margin. The cortical bone measures some $10 \mathrm{~mm}$ in thickness, but the dark color layer does not extend beyond $2 \mathrm{~mm}$ inside the bone. Scale bar $=50 \mathrm{~mm}$.

Haversian channels, and although influenced by bone porosity, microenvironment and composition of the surrounding matrix, climate is the main factor that controls its incorporation (Houston et al., 1966; Parker \& Toots, 1970). Along Chuí Creek, iron is relatively abundant in the fossiliferous bed, in the form of iron oxide nodules and crusts around root traces and coatings on sand grains (Lopes et al., 2001, 2011). The presence of these iron minerals in the sediments indicates oxidizing conditions, under seasonally warm climate and high mean annual precipitation (Maignien, 1966). 
Like iron, manganese is incorporated as fillings and produces black-stained surfaces; its absence in recent specimens indicates that adsorption occurs during diagenesis and depends on the depositional environment. Manganese is a common element in seawater, and the formation of nodules in marine environment and of varnish coatings in continental settings involves the action of manganese-oxidizing bacteria (Bauman, 1976; Shahack-Gross et al., 1997). Just like strontium, barium occurs in bones as a substitute for calcium; although its concentration is diet-sensitive and decreases from lower to higher trophic levels (Ezzo, 1992) its presence only in two fossil suggests a diagenetic rather than dietary origin in the samples analyzed here.

Sulphur was found only in fossils with the highest iron content. The presence of this element is probably related to the characteristics of the depositional environment. Under reducing conditions in organic matter-rich environments with iron available in the sediment, bacterial activity reduces sulphates, producing iron sulfide in the form of pyrite, $\mathrm{FeS}_{2}$ (Tucker, 1992). Many pink-colored fossils from Chuí Creek are found in organic matter-rich fluvial deposits (oxbow lakes) that contain palynomorphs indicative of low hydrodynamics; these lenses are always bounded above and below by ironrich horizons, which indicate seasonal conditions (Lopes et al., 2009). These features suggest that during periods of stagnant water, biological activity could have lowered the oxygen levels and allowed the bacteria to produce iron sulfide, which would later be incorporated to bone remains preserved in such lenses.

The only remains containing scandium were the two osteodermos from the continental shelf. The presence of this element can be related to the presence of iron-manganese minerals in the sediment matrix, which incorporate scandium and cobalt into the oxide while percolating with pore water through the vadose zone under oxidizing conditions (Williams \& Potts, 1988). Zinc and zirconium are present in the recent osteoderm but not in the fossil ones. This could be due to dietary differences, or to the loss or replacement of these elements because of diagenetic modifications. The concentration of zinc in bone tissue of carnivores are higher than in herbivores (Rheingold \& Hues, 1983; Francalacci, 1989; Subirà \& Malgosa, 1992); the amount of this element found in the modern cow and fossil rib is similar, suggesting that the latter was also from a herbivore.

The overall similarity in trace metal content between the fossil from Chuí Creek and those from the continental shelf maybe points out to an early diagenetic phase in continental environment for the latter, during which iron, manganese, barium and sulphur were incorporated. This phase was followed by a second diagenesis in marine environment, resulting from erosion and reworking of the shelf deposits by sea-level transgressions (Lopes \& Buchmann, 2010). During this phase, elements not found in the fossil from Chuí Creek, such as scandium, most of the strontium, yttrium and titanium were incorporated. Small differences in composition among these remains are likely to reflect dietary variations and/or local depositional conditions.

\section{CONCLUSIONS}

The post mortem modifications (pseudopaleopathologies) observed in mammalian fossils from the three assemblages are probably related to the intrinsic features of the distinct skeletal elements, to specific environmental conditions at the site of final burial, and to post-depositional reworking. The most conspicuous pseudopaleopathologies observed are fractures caused by mechanical processes, crackings that result from weathering processes, abrasion signs related to transportation of the remains, and variations in color and hardness related to geochemical processes. Other less evident modifications include the deposition of calcium carbonate, the formation of crusts of iron oxide or beach rock, bioerosion by invertebrates or plants and breakage by carnivores.

Most of the signs of fracturing in incomplete/fragmented fossils were produced by post-depositional reworking, indicated by plain fractures transverse to the structure of the bones. The absence of evidence of pre-fossilization fracturing (and gnawing marks) suggests that predation or scavenging were not directly involved in the origin of the studied assemblages, although may have played a role in the relatively low number of elements of Voorhies'group II in the Chuí Creek assemblage.

Although many fossils from the Campanha and Chuí Creek are incomplete or fragmented, the absence of abrasion indicates that the reworking of these remains did not involve transportation for long periods or distances. The high degree of abrasion in fossils from the continental shelf, on the other hand, indicate that these were reworked by waves and currents in shallow marine setting for long periods prior to collecting.

The relatively low number of weathered fossils from Chuí Creek and continental shelf suggests that these were buried in less time in comparison to those from the Touro Passo Formation, probably related to differences in depositional conditions (e.g. fluvial regime). The EDX analysis shows that geochemical processes, which vary according to the depositional environment, are the main control on the incorporation or substitution of elements in the fossilized remains, although some variations are possibly related to dietary differences.

\section{ACKNOWLEDGEMENTS}

This work was possible by financial support provided by CAPES (research grant for R.P. Lopes). The authors express their gratitude to N.L.V. Carreño and G.C. Link (UFPel) for providing the EDX analyses.

\section{REFERENCES}

Aires, A.A.S. \& Lopes, R.P. 2012. Representativity of Quaternary mammals from the southern Brazilian continental shelf. Revista Brasileira de Paleontologia, 15:57-66. doi:10.4072/ rbp.2012.1.05

Andrés, M.; Gidna, A.O.; Yravedra, J. \& Domínguez-Rodrigo, M. 2011. A study of dimensional differences of tooth marks (pits and scores) on bones modified by small and large carnivores. 
Archaeological and Anthropological Sciences, 4:209-219. doi:10.1007/s12520-012-0093-4

Andrews, P. \& Fernández-Jalvo, Y. 1997. Surface modifications of the Sima de Los Huesos fossil humans. Journal of Human Evolution, 33:191-217. doi:10.1006/jhev.1997.0137

Aslan, A. \& Behrensmeyer, A.K. 1996. Taphonomy and time resolution of bone assemblages in a contemporary fluvial system: the East Fork River, Wyoming. Palaios, 11:411-421. doi:10.2307/3515209

Aufderheide, A.C. \& Rodríguez-Martín, C. 1998. The Cambridge Encyclopedia of Human Paleopathology. Cambridge, Cambridge University Press, 475 p.

Badgley, C.; Bartels, W.S.; Morgan, M.E.; Behrensmeyer, A.K. \& Raza, S.M. 1995. Taphonomy of vertebrate assemblages from the Paleogene of northwestern Wyoming and the Neogene of northern Pakistan. Palaeogeography, Palaeoclimatology, Palaeoecology, 115:157-180. doi:10.1016/0031-0182(94)00110-T

Bartosiewicz, L. 2008. Taphonomy and palaeopathology in archaeozoology. Geobios, 41:69-77. doi:10.1016/j. geobios.2006.02.004

Bauman, A.J. 1976. Desert varnish and marine ferromanganese oxide nodules: congeneric phenomena. Nature, 259:387-388. doi:10.1038/259387a0

Behrensmeyer, A.K. 1978. Taphonomic and ecologic information from bone weathering. Paleobiology, 4:150-162.

Behrensmeyer, A.K. 1982. Time resolution in fluvial vertebrate assemblages. Paleobiology, 8:211-227.

Behrensmeyer, A.K. 1991. Terrestrial vertebrate accumulations. In: P.A. Allison \& D.E.G. Briggs (eds.) Taphonomy: releasing the data locked in the fossil record, Plenum Press, p. 291-329.

Behrensmeyer, A.K. \& Kidwell, S.M. 1985. Taphonomy's contributions to paleobiology. Paleobiology, 11:105-119.

Bell, L.S.; Skinner, M.F. \& Jones, S.J. 1996. The speed of post mortem change to the human skeleton and its taphonomic significance. Forensic Science International, 82:129-140.

Bharti, M. \& Singh, D. 2003. Insect faunal succession on decaying rabbit carcasses in Punjab, India. Journal of Forensic Science, 48:1-11.

Binford, L.R.; Mills, M.G.L. \& Stone, N.M 1988. Hyena scavenging behavior and its implications for the interpretation of fauna1 assemblages from FLK 22 (the Zinj Floor) at Olduvai Gorge. Journal of Anthropological Archaeology, 7:99-135. doi:10.1016/0278-4165(88)90011-6

Blumenschine, R.J. 1986. Carcass consumption sequences and the archaeological distinction of scavenging and hunting. Journal of Human Evolution, 15:639-659. doi:10.1016/S00472484(86)80002-1

Blumenschine, R.J.; Marean, C.W. \& Capaldo, S.D. 1996. Blind-tests of inter-analyst correspondence and accuracy in the identification of cut marks, percussion marks, and carnivore tooth marks on bone surfaces. Journal of Archaeological Science, 23:493-507. doi:10.1006/jasc.1996.0047

Bombin, M. 1976. Modelo paleo-ecológico evolutivo para o neoQuaternário da região da Campanha - oeste do Rio Grande do Sul (Brasil). Formação Touro Passo, seu conteúdo fossilífero e a pedogênese pós-deposicional. Programa de Pós-Graduação em Geociências, Universidade Federal do Rio Grande do Sul, M.Sc. Dissertation, 133 p.

Bombin, M. \& Klamt, E. 1975. Evidências paleoclimáticas em solos do Rio Grande do Sul. Comunicações do Museu de Ciências da PUCRS, 13:183-193.
Branner, J.C. 1904. The stone reefs of Brazil, their geological and geographical relations, with a chapter on the coral reefs. Cambridge, Museum of Comparative Zoology, John Wilson \& Son, 285 p. (Bulletin 44).

Brett, C.E. \& Baird, C.G. 1986. Comparative taphonomy: a key to paleoenvironmental interpretation based on fossil preservation. Palaios, 1:207-227. doi:10.2307/3514686

Buchmann, F.S.C.; Caron, F.; Lopes, R.P.; Ugri, A. \& Lima, L.G. 2009. Panorama Geológico da Planície Costeira do Rio Grande do Sul. In: A.M. Ribeiro; S.G. Bauermann \& C.S. Scherer (eds.) Quaternário do Rio Grande do Sul: integrando conhecimentos, Porto Alegre, Sociedade Brasileira de Paleontologia, p. 35-56 (Monografias 1).

Cione, A.L. \& Tonni, E.P. 1999. Biostratigraphy and chronological scale of upper-most Cenozoic in the Pampean Area, Argentina. In: J. Rabassa \& M. Salemme (eds) Quaternary of South America and Antarctic Peninsula, Rotterdam, A.A. Balkema, p. 23-51 (Volume 12).

Cruz Jr., F.W.; Burns, S.J.; Karmann, I.; Sharp, W.D.; Vuille, M.; Cardoso, A.O.; Ferrari, J.A.; Dias, P.L.S. \& Viana Jr., O. 2005. Insolation-driven changes in atmospheric circulation over the past 116,000 years in subtropical Brazil. Nature, 434:63-66. doi:10.1038/nature03365

Cunha, F.L.S. 1959. Mamíferos Fósseis do Pleistoceno do Rio Grande do Sul I - Ungulados. Rio de Janeiro, Departamento Nacional de Produção Mineral, Divisão de Geologia e Mineralogia, 47 p. (Boletim 202).

Cutler, A.H.; Behrensmeyer, A.K. \& Chapman, R.E. 1999. Environmental information in a recent bone assemblage: roles of taphonomic processes and ecological change. Palaeogeography, Palaeoclimatology, Palaeoecology, 149:359-372. doi:10.1016/ S0031-0182(98)00212-0

D’Andrea, A.C. \& Gotthardt, R.M. 1984. Predator and scavenger modification of recent equid skeletal assemblages. Arctic, 37:276-283. doi:10.14430/arctic2201

Da Rosa, A.A.S. 2003. Preliminary correlation of fluvial deposits at the extreme west of Rio Grande do Sul State, Southern Brazil. In: LATINAMERICAN CONGRESS OF SEDIMENTOLOGY, 3, 2003. Abstract Book, Belém, p. 243-244.

Da Rosa, A.A.S. 2009. Geologia do Quaternário continental do RS: situação atual e perspectivas de trabalho. In: A.M. Ribeiro; S.G. Bauermann \& C.S. Scherer (eds.) Quaternário do Rio Grande do Sul: integrando conhecimentos, Porto Alegre, Sociedade Brasileira de Paleontologia, p. 17-34 (Monografias 1).

Da Rosa, A.A.S. \& Milder, S.E.S. 2001. Aloformação Guterrez: uma nova unidade estratigráfica para o extremo oeste do oeste do Estado do Rio Grande do Sul. In: CONGRESSO DA ASSOCIAÇÃO BRASILEIRA DE ESTUDOS DO QUATERNÁRIO, 8, 2001. Boletim de Resumos, Imbé, p. 253-254.

Defleur, A.; White, T.; Valensi, P.; Slimak, L. \& Crégut-Bonnoure, E. 1999. Neanderthal cannibalism at Moula-Guercy, Ardèche, France. Science, 286:128-131. doi:10.1126/science.286.5437.128

Delaney, P.J.V. 1965. Fisiografia e geologia da superfície da planície costeira do Rio Grande do Sul. Porto Alegre, Escola de Geologia, Universidade Federal do Rio Grande do Sul, 195 p. (Publicação Especial 6).

Dillenburg, S.R. 1994. O potencial de preservação dos registros sedimentares do Sistema Deposicional Laguna/Barreira IV na costa do Rio Grande do Sul. Notas Técnicas, 9:1-11.

Domínguez-Rodrigo, M. \& Piqueras, A. 2003. The use of tooth pits to identify carnivore taxa in tooth-marked archaeofaunas 
and their relevance to reconstruct hominid carcass processing behaviours. Journal of Archaeological Science, 30:1385-1391. doi:10.1016/S0305-4403(03)00027-X

Efremov, I. 1940. Taphonomy: new branch of paleontology. PanAmerican Geologist, 74:81-93.

Ezzo, J.A. 1992. A test of diet versus diagenesis at Ventana Cave, Arizona. Journal of Archaeological Science, 19:23-37. doi:10.1016/0305-4403(92)90004-M

Fariña, R.; Vizcaíno, S.F. \& Bargo, M.S. 1998. Body mass estimations in Lujanian (Late Pleistocene - Early Holocene of South America) mammal megafauna. Mastozoología Neotropical, 5:87-108.

Fejfar, O. \& Kaiser, T.M. 2005. Insect bone-modification and paleoecology of Oligocene mammal-bearing sites in the Doupov mountains, northwestern Bohemia. Palaeontologia Electronica, 8:8A.

Ferigolo, J. 1992. Non-human vertebrate paleopathology of some Brazilian Pleistocene mammals. In: A.J.G. Araújo \& L.F. Ferreira (eds.) Paleopatologia e Paleoepidemiologia: estudos multidisciplinares, Escola Nacional de Saúde Pública, p. 213-234.

Ferigolo, J. 2007. Paleopatologia em mamíferos. In: I.S. Carvalho \& A.C.S. Fernandes (eds.) Icnologia, São Paulo, Sociedade Brasileira de Geologia, p. 88-107 (Série Textos 3).

Fernández-Jalvo, Y. \& Andrews, P. 1992. Small mammal taphonomy of Gran Dolina, Atapuerca (Burgos), Spain. Journal of Archaeological Science, 19:407-428. doi:10.1016/03054403(92)90058-B

Francalacci, P. 1989. Dietary reconstruction at Arene Candide Cave (Liguria, Italy) by means of trace element. Journal of Archaeological Science, 16:109-124. doi:10.1016/03054403(89)90060-5

Haynes, G.A. 1980. Evidence of carnivore gnawing on Pleistocene and recent mammalian bones. Paleobiology, 6:341-351.

Haynes, G.A. 1983. A guide for differentiating mammalian carnivore taxa responsible for gnaw damage to herbivore limb bones. Paleobiology, 9:164-172.

Hedges, R.E.M. 2002. Bone diagenesis: an overview of processes. Archaeometry, 44:319-328. doi:10.1111/1475-4754.00064

Hill, A. 1979. Disarticulation and scattering of mammal skeletons. Paleobiology, 5:261-274.

Holz, M. \& Souto-Ribeiro, A. 2000. Taphonomy of the southBrazilian Triassic vertebrates. Revista Brasileira de Geociências, 30:491-494.

Holz, M. \& Simões, M.G. 2002. Elementos fundamentais de Tafonomia. Porto Alegre, Editora da Universidade Federal do Rio Grande do Sul, 231 p.

Houston, R.R.; Toots, H. \& Kelley, J.C. 1966. Iron content of fossil bones of Tertiary age in Wyoming correlated with climatic change. Rocky Mountain Geology, 5:1-18.

Janjua, M. \& Rogers, T.L. 2008. Bone weathering patterns of metatarsal v. femur and the postmortem interval in Southern Ontario. Forensic Science International, 178:16-23. doi:10.1016/j.forsciint.2008.01.011

Jans, M.M.E.; Kars, H.; Nielsen-Marsh, C.M.; Smith, C.I.; Nord, A.G.; Arthur, P. \& Earl, N. 2002. In situ preservation of archaeological bone: a histological study within a multidisciplinary approach. Archaeometry, 44:343-352. doi:10.1111/1475-4754.t01-1-00067

Kaiser, T.M. 2000. Proposed insect modification to fossil mammalian bone from Plio-Pleistocene hominid-bearing deposits of Laetoli (northern Tanzania). Annals of the Entomological Society of America, 93:693-700. doi:10.1603/00138746(2000)093[0693:pfimtf]2.0.co;2
Kerber, L.; Kinoshita, A.; José, F.A.; Figueiredo, A.M.; Oliveira, E.V. \& Baffa, O. 2011a. Electron Spin Resonance dating of the southern Brazilian Pleistocene mammals from Touro Passo Formation, and remarks on the geochronology, fauna and palaeoenvironments. Quaternary International, 245:201-208. doi:10.1016/j.quaint.2010.10.010

Kerber, L.; Lopes, R.P.; Oliveira, E.V.; Ribeiro, A.M. \& Pereira, J.C. 2012. On the presence of Holochilus brasiliensis (Desmarest, 1819) (Rodentia: Cricetidae: Sigmodontinae) in the late Pleistocene of southern Brazil. Gaea, 8:47-54. doi:10.4013/ gaea.2012.82.02

Kerber, L.; Lopes, R.P.; Vucetich, M.G.; Ribeiro, A.M. \& Pereira, J.C. 2011b. Chinchillidae and Dolichotinae rodents (Rodentia, Hystricognathi, Caviomorpha) from the late Pleistocene of southern Brazil. Revista Brasileira de Paleontologia, 14:229238. doi:10.4072/rbp.2011.3.03

Kerber, L. \& Oliveira, E.V. 2008. Fósseis de vertebrados da Formação Touro Passo (Pleistoceno Superior), Rio Grande do Sul, Brasil: atualização dos dados e novas contribuições. Gaea, 4:49-64.

Kerber, L. \& Ribeiro, A.M. 2011. Capybaras (Rodentia: Hystricognathi: Hydrochoeridae) from the late Pleistocene of southern Brazil. Neues Jahrbuch für Geologie und Paläontologie - Abhandlungen, 261:1-18. doi:10.1127/0077-7749/2011/0142

Kholodov, V.N. 2007. Caliches: a newly-formed boundary carbonate material in soils. Lithology and Mineralogy Resources, 42:246256. doi:10.1134/S0024490207030042

Klappa, C.F. 1980. Rhizoliths in terrestrial carbonates: classification, recognition, genesis and significance. Sedimentology, 27:613629. doi:10.1111/j.1365-3091.1980.tb01651.x

Klippel, W.E. \& Synstelien, J.A. 2007. Rodents as taphonomic agents: bone gnawing by brown rats and gray squirrels. Journal of Forensic Sciences, 52:765-773. doi:10.1111/j.15564029.2007.00467.x

Lima, L.G.; Dillenburg, S.R.; Medeanic, S.; Barboza, E.G.; Rosa, M.L.C.C.; Tomazelli, L.J.; Dehnhardt, B.A. \& Caron, F. 2013. Sea-level rise and sediment budget controlling the evolution of a transgressive barrier in southern Brazil. Journal of South American Earth Sciences, 42:27-38. doi:10.1016/j. jsames.2012.07.002

Lisiecki, L.E. \& Raymo, M.E. 2005. A Pliocene-Pleistocene stack of 57 globally distributed benthic $\delta^{18} \mathrm{O}$ records. Paleoceanography, 20:PA1003. doi:10.1029/2004PA001071

Lopes, R.P. 2012. Bioerosion and bioincrustation in body fossils from the Coastal Plain of Rio Grande do Sul state, southern Brazil. In: R.G. Netto; N.B. Carmona \& F.M.W. Tognoli. (Orgs.) Ichnology of Latin America - Selected Papers, Porto Alegre, Sociedade Brasileira de Paleontologia, p. 179-194 (Monografias 2).

Lopes, R.P. \& Buchmann, F.S.C. 2011. Pleistocene mammals from the southern Brazilian continental shelf. Journal of South American Earth Sciences, 31:17-27. doi:10.1016/j. jsames.2010.11.003

Lopes, R.P.; Buchmann, F.S.C. \& Caron, F. 2008. Taphonomic analysis on fossils of Pleistocene mammals from deposits submerged along southern Rio Grande do Sul coastal plain, Brazil. Arquivos do Museu Nacional, 66:213-229.

Lopes, R.P.; Buchmann, F.S.C.; Caron, F. \& Itusarry, M.E. 2001. Tafonomia dos fósseis de vertebrados (megafauna extinta) encontrados ao longo das barrancas do arroio Chuí e linha de costa, RS, Brasil. Pesquisas, 28:67-73.

Lopes, R.P.; Buchmann, F.S.C.; Caron, F. \& Itusarry, M.E. 2009. Barrancas fossilíferas do arroio Chuí, RS - importante megafauna pleistocênica no extremo sul do Brasil. In: M. Winge; C. 
Schobbenhaus; M. Berbert-Born; E.T. Queiroz; D.A. Campos; C.R.G. Souza \& A.C.S. Fernandes (eds.) Sítios Geológicos e Paleontológicos do Brasil, Serviço Geológico do Brasil, Comissão Brasileira de Sítios Geológicos e Paleobiológicos, p. 355-362.

Lopes, R.P.; Dillenburg, S.R. \& Schultz, C.L. 2011. Geological and environmental evolution of Lagoon System III in the southernmost coastal plain of Rio Grande do Sul state. In: CONGRESSO DA ASSOCIAÇÃO BRASILEIRA DE ESTUDOS DO QUATERNÁRIO ABEQUA, 13, 2011. Available at http://www.abequa.org.br/trabalhos/ABEQUA_2011_ STRATIGRAPHY-FINAL.pdf; accessed on 22/04/2015.

Lopes, R.P.; Kinoshita, A.; Baffa, O.; Figueiredo, A.M.G.; Dillenburg, S.R.; Schultz, C.L. \& Pereira, J.C. 2014. ESR dating of Pleistocene mammals and marine shells from the coastal plain of Rio Grande do Sul state, Southern Brazil. Quaternary International, 352:124-134. doi:10.1016/j.quaint.2013.07.020

Lopes, R.P.; Oliveira, L.C.; Figueiredo, A.M.G.; Kinoshita, A.; Baffa, O. \& Buchmann, F.S.C. 2010. ESR dating of Pleistocene mammal teeth and its implications for the biostratigraphy and geological evolution of the coastal plain, Rio Grande do Sul, southern Brazil. Quaternary International, 212:213-222. doi:10.1016/j. quaint.2009.09.018

Lopes, R.P. \& Pereira, J.C. 2010. Fossils of Scelidotheriinae Ameghino, 1904 (Xenarthra, Pilosa) in the Pleistocene deposits of Rio Grande do Sul, Brazil. Gaea, 6:44-52. doi:10.4013/ gaea.2010.61.05

Lopes, R.P.; Simone, L.R.L.; Dillenburg, S.R.; Schultz, C.L. \& Pereira, J.C. 2013. A middle Pleistocene marine molluscan assemblage from the Southern coastal plain of Rio Grande do Sul State. Revista Brasileira de Paleontologia, 16:343-360. doi:10.4072/rbp.2013.3.01

Lyman, R.L. 2005. Analyzing cut marks: lessons from artiodactyl remains in the northwestern United States. Journal of Archaeological Science, 32:1722-1732. doi:10.1016/j. jas.2005.06.003

MacDonald, N.S.; Nusbaum, R.E.; Alexander, G.V.; Ezmirlian, F.; Spain, P. \& Rounds, D.E. 1952. The skeletal deposition of yttrium. Journal of Biological Chemistry, 195:837-841.

Maignien, R. 1966. Review of research on laterites. Liège, UNESCO, $148 \mathrm{p}$.

Marcon, G.T.G. 2007. Contribuição ao estudo dos Proboscidea (Mammalia, Gomphotheriidae) do Quaternário do Estado do Rio Grande do Sul, Brasil. Programa de Pós-Graduação em Geociências, Universidade Federal do Rio Grande do Sul, M.Sc. Dissertation, 113 p.

Martill, D.M. 1992. Bones as stones: the contribution of vertebrate remains to the lithologic record. In: A.K. Behrensmeyer \& A.P. Hill (eds.) Fossils in the Making - Vertebrate Taphonomy and Paleoecology, University of Chicago Press, p. 270-292.

Mello, M.G.S. 1999. Sistematização de critérios para diagnóstico diferencial entre paleopatologias e sinais de alterações análogas: fundamentos teórico-metodológicos. Escola Nacional de Saúde Pública, Fundação Oswaldo Cruz, Ph.D. Thesis, 211 p.

Montalvo, C.I. 2002. Root traces in fossil bones from the Huayquerian (Late Miocene) faunal assemblage of Telén, La Pampa, Argentina. Acta Geologica Hispanica, 37:37-42.

Montalvo, C.I.; Pessinoa, M.E.M. \& Bagattoa, F.C. 2008. Taphonomy of the bones of rodents consumed by Andean hog-nosed skunks (Conepatus chinga, Carnivora, Mephitidae) in central Argentina. Journal of Archaeological Science, 35:1481-1488. doi:10.1016/j. jas.2007.10.011
Moura, M.O.; Carvalho, C.J.B. \& Monteiro-Filho, E.L.A. 1997. A preliminary analysis of insects of medico-legal importance in Curitiba, State of Paraná. Memórias do Instituto Oswaldo Cruz, 92:269-274. doi:10.1590/s0074-02761997000200023

Oliveira, E.V. 1992. Mamíferos fósseis do Pleistoceno Superior Holoceno do Rio Grande do Sul, e seu signific ado paleoecológico. Programa de Pós-Graduação em Geociências, Universidade Federal do Rio Grande do Sul, M.Sc. Dissertation, 118 p.

Oliveira, E.V.; Prevosti, F.J. \& Pereira, J.C. 2005. Protocyon troglodytes (Lund) (Mammalia, Carnivora) in the Late Pleistocene of Rio Grande do Sul and their paleoecological significance. Revista Brasileira de Paleontologia, 8:215-220.

Ortner, D.J. \& Putschar, W.G. 1980. Identification of pathological conditions in human skeletal remains. Washington, Smithsonian Institution Press, 479 p. (Contributions to Anthropology 28). doi:10.5479/si.00810223.28.1

Palmqvist, P. \& Arribas, A. 2001. Taphonomic decoding of the paleobiological information locked in a lower Pleistocene assemblage of large mammals. Paleobiology, 27:512-530. doi:10.1666/0094-8373(2001)027<0512:TDOTPI>2.0.CO;2

Parker, R.B. \& Toots, H. 1970. Minor elements in fossil bone. Geological Society of America Bulletin, 81:925-932. doi:10.1130/0016-7606(1970)81[925:MEIFB]2.0.CO;2

Parker, R.B. \& Toots, H. 1980. Trace elements in bones as paleobiological indicators. In: A.K Behrensmeyer \& A.P. Hill (eds.) Fossils in the making - vertebrate taphonomy and paleoecology, University of Chicago Press, p. 197-207.

Paula Couto, C. \& Cunha, F.L.S. 1965. Nota preliminar sobre o reconhecimento geo-paleontológico do Rio Grande do Sul. Rio de Janeiro, Departamento Nacional de Produção Mineral, Divisão de Geologia e Mineralogia, p. 49-50 (Boletim 40).

Pereira, J.C.; Lopes, R.P. \& Kerber, L. 2012. New remains of Late Pleistocene mammals from the Chuí Creek, southern Brazil. Revista Brasileira de Paleontologia, 15:228-239. doi:10.4072/rbp.2012.2.10.

Pirrone, C.A.; Buatois, L.A. \& Bromley, R.G. 2014. Ichnotaxobases for bioerosion trace fossils in bones. Journal of Paleontology, 88:195-203. doi:10.1666/11-058

Pitana, V.G.; Scherer, C. \& Ribeiro, A.M. 2005. Um Proterotheriidae (Mammalia, Litopterna) do Quaternário do Estado do Rio Grande do Sul, Brasil. In: CONGRESSO LATINO-AMERICANO DE PALEONTOLOGIA DE VERTEBRADOS, 2, 2005. Livro de Resumos, Rio de Janeiro, p. 205-206.

Prevosti, F.J. \& Vizcaíno, S.F. 2006. Paleoecology of the large carnivore guild from the Late Pleistocene of Argentina. Acta Palaeontologica Polonica, 51:407-422.

Rheingold, A.L. \& Hues, S. 1983. Strontium and zinc content in bones as an indication of diet. Journal of Chemical Education, 60:233-234. doi:10.1021/ed060p233

Ribeiro, A.M. \& Scherer, C.S. 2009. Mamíferos do Pleistoceno do Rio Grande do Sul. In: A.M. Ribeiro; S.G. Bauermann \& C.S. Scherer (eds.) Quaternário do Rio Grande do Sul: integrando conhecimentos, Porto Alegre, Sociedade Brasileira de Paleontologia, p. 171-191 (Monografias 1).

Rodrigues, P.H. \& Ferigolo, J. 2004. Roedores pleistocênicos da Planície Costeira do Estado do Rio Grande do Sul, Brasil. Revista Brasileira de Paleontologia, 7:231-238.

Rodrigues, P.H.; Prevosti, F.J.; Ferigolo, J. \& Ribeiro, A.M. 2004. Novos materiais de Carnivora para o Pleistoceno do estado do Rio Grande do Sul, Brasil. Revista Brasileira de Paleontologia, 7:77-86. 
Rogers, E.M.; Rogers, R.R. \& Foreman, B.Z. 2007. Continental insect borings in dinosaur bone: examples from the Late Cretaceous of Madagascar and Utah. Journal of Paleontology, 81:201-208. doi:10.1666/0022-3360(2007)81[201:CIBIDB]2 $.0 . \mathrm{CO} ; 2$

Russell, R.J. \& McIntire, W.G. 1965. Southern Hemisphere beach rock. Geographical Review, 55:17-45. doi:10.2307/212853

Safont, S.; Malgosa, A.; Subirà, M.E. \& Gibert, J. 1998. Can trace elements in fossils provide information about palaeodiet? International Journal of Osteoarchaeology, 8:2337. doi:10.1002/(SICI)1099-1212(199801/02)8:1<23::AID$O A 403>3.0 . C O ; 2-R$

Scherer, C.S.; Ferigolo, J.; Ribeiro, A.M. \& Cartelle, C. 2007. Contribution to the knowledge of Hemiauchenia paradoxa (Artiodactyla, Camelidae) from the Pleistocene of southern Brazil. Revista Brasileira de Paleontologia, 10:35-52. doi:10.4072/rbp.2007.1.04

Schmitz, P.I.; Girelli, M. \& Rosa, A.O. 1997. Pesquisas arqueológicas em Santa Vitória do Palmar, RS. In: P.I. Schmitz (ed.) Arqueologia do Rio Grande do Sul, Brasil, São Leopoldo, Instituto Anchietano de Pesquisas-UNISINOS, 95 p. (Documentos 7).

Selvaggio, M.M. 1994. Carnivore tooth marks and stone tool butchery marks on scavenged bones: archaeological implications. Journal of Human Evolution, 27:215-228. doi:10.1006/jhev.1994.1043

Shahack-Gross, R.; Bar-Yosef, O. \& Weiner, S. 1997. Black-coloured bones in Hayonim Cave, Israel: differentiating between burning and oxide staining. Journal of Archaeological Science, 24:439446. doi:10.1006/jasc.1996.0128

Subirà, M.E. \& Malgosa, A. 1992. Multi-element analysis for dietary reconstruction at a Balearic Iron Age Site. International Journal of Osteoarchaeology, 2:199-204. doi:10.1002/oa.1390020303

Tappen, M. 1994. Bone weathering in the tropical rain forest. Journal of Archaeological Science, 21:667-673. doi:10.1006/ jasc.1994.1066
Toots, H. 1965. Sequence of disarticulation in mammalian skeletons. Rocky Mountain Geology, 4:37-39.

Trueman, C.N. \& Tuross, N. 2002. Trace elements in recent and fossil bone apatite. Reviews in Mineralogy and Geochemistry, 48:489-521. doi:10.2138/rmg.2002.48.13

Tucker, M.E. 1992. The diagenesis of fossils. In: S.K. Donovan (ed.) The Processes of Fossilization, CBS Publishers, p. 84-104.

Tuross, N.; Behrensmeyer, A.K.; Eanes, E.D. \& Fisher, L.W. 1989. Molecular preservation and crystallographic alterations in a weathering sequence of wildebeest bones. Apllied Geochemistry, 4:261-270. doi:10.1016/0883-2927(89)90027-9

Ubilla, M.; Oliveira, E.V.; Rinderknecht, A. \& Pereira, J. 2008. The hystricognath rodent Microcavia in the Late Pleistocene of Brazil (Rio Grande do Sul, South America) (Mammalia: Caviidae). Biogeographic and paleoenvironmental implications. Neues Jahrbüch für Geologie und Paläontologie - Abhandlungen, 247:15-21. doi:10.1127/0077-7749/2008/0247-0015

Villwock, J.A. \& Tomazelli, L.J. 1995. Geologia Costeira do Rio Grande do Sul. Notas Técnicas, 8:1-45.

Voorhies, M.R. 1969. Taphonomy and population dynamics of an early Pliocene vertebrate fauna, Knox County, Nebraska. Rocky Mountain Geology, 8:1-69. doi:10.2113/gsrocky.8.special_ paper_1.1

Waldron, T. 2009. Paleopathology. New York, Cambridge University Press, $279 \mathrm{p}$.

Waldron, T. 2011. Joint Disease. In: A.L. Grauer (ed.) A Companion to Paleopathology, John Wiley \& Sons, p. 513-530.

Williams, C.T. \& Potts, P.J. 1988. Element distribution maps in fossil bones. Archaeometry, 30:237-247. doi:10.1111/j.1475-4754.1988. tb00450.x

Received in September, 2014; accepted in April, 2015. 